\title{
The rainbow is our sovereignty: Rethinking the politics of energy on the Navajo Nation
}

\author{
Dana E. Powell ${ }^{1}$ \\ Appalachian State University, USA
}

\begin{abstract}
This article offers a political-ecological reflection on Navajo (Diné) sovereignty, emphasizing lived and territorial interpretations of sovereignty, expanding our standard, juridical-legal notions of sovereignty that dominate public discourse on tribal economic and energy development. Operating from a critical analysis of settler colonialism, I suggest that alternative understandings of sovereignty - as expressed by Diné tribal members in a range of expressive practices - open new possibilities for thinking about how sovereign futures might be literally constructed through specific energy infrastructures. The article follows the controversy surrounding a proposed coal fired power plant known as Desert Rock, placing the phantom project in a longer, enduring history of struggle over energy extraction on Navajo land in order to illuminate this contested future. Broadly, these re-significations of sovereignty point toward a distinct modality of environmental action that suggests other kinds of relationships are at stake, challenging assumptions made by adversaries and allies alike that the politics of protesting (in this case) coal technologies is a practice with self-evident ethics. To intervene in these broad debates, I propose that there are multiple landscapes of power shaping Navajo territory, which must be brought into the ongoing, urgent debates over how the Navajo Nation might develop a more sustainable energy policy for the future.
\end{abstract}

Keywords: political ecology, sovereignty, Navajo, environmentalism, ethics, territory, practice, sustainability, landscapes of power

\section{Résumé}

Cet article propose une réflexion politico-écologique sur la souveraineté Navajo (Diné), soulignant les interprétations vécues et territoriaux de la souveraineté, l'élargissement des notions juridiques standards de la souveraineté qui dominent le discours public sur le développement économique et de l'énergie tribale. Fonctionnant à partir d'une analyse critique de colonialisme, je suggère que d'autres conceptions de la souveraineté - telles qu'exprimées par les membres tribaux Diné dans un gamme de pratiques expressives offrent de nouvelles possibilités pour penser à la façon la terme souveraineté pourrait être construit littéralement à travers des infrastructures énergétiques spécifiques. L'article fait suite à la controverse entourant une station proposée énergie au charbon, Desert Rock, plaçant le projet fantôme dans une histoire de lutte pour l'extraction de l'énergie sur les terres Navajo pour éclairer cet avenir contestée. Globalement, ces re-significations de la souveraineté suggèrent une modalité d'action environnementale distinct dans lequel d'autres types de relations sont mise en cause. Ils remettent en cause les hypothèses formulées par les adversaires et alliés que la politique de protester (dans ce cas) les technologies du charbon est éthiquement correct, et évident. Pour intervenir dans ces grands débats, je propose qu'il existe plusieurs paysages de pouvoir façonner le territoire Navajo, qui doivent être introduits dans les débats en cours, sur la façon dont la Nation Navajo pourrait élaborer une politique énergétique plus durable pour l'avenir. Mots-clés: écologie politique, la souveraineté, Navajo, l'environnementalisme, l'éthique, le territoire, la pratique, la durabilité, les paysages du pouvoir

\footnotetext{
${ }^{1}$ Dr. Dana E. Powell, Assistant Professor of Anthropology, Appalachian State University, Boone, North Carolina, USA. Email: powellde@appstate.edu. Powell's research examines the cultural politics of energy development in Native Nations and supports social movements working on building sustainable infrastructure on indigenous territories and elsewhere. Research has been supported by the Wenner-Gren Foundation, the NSF, Royster Society of Fellows at the University of North Carolina-Chapel Hill, and the University Research Council at Appalachian State University. Acknowledgements: for comments on earlier versions of this paper, Jean Dennison, Andrew Curley, Courtney Lewis, Jonathan Soffer, Gabriela Valdivia, Kristina Jacobsen-Bia, Andrew Needham, Renee Scherling, Leslie McLees, Carrie Bush, Brian Burke, Cynthia Wood, Dinesh Paudel, and Billy Schumann; and collaborators, without whom this research would not have been possible: Earl Tulley, Adella Begaye, Robyn Jackson, Ed Singer, Ron Maldonado and the NNHPD, Mike Eisenfeld, Sarah Jane White, Lori Goodman, Anna Frazier, and Dailan J. Long.
} 


\section{Resumen}

Este artículo ofrece una reflexión político-ecológica sobre la soberanía Navajo (Diné), enfatizando interpretaciones vividas y territoriales de la soberanía, expandiendo de tal modo nuestras nociones estándar jurídico-legales de soberanía que dominan el discurso público sobre la economía tribal y el desarrollo energético. Operando desde un análisis crítico del colonialismo del asentamiento, sugiero que entendimiento alternativos de soberanía -expresado por miembros de la tribu Diné en determinadas prácticas expresivasabren nuevas posibilidades para pensar sobre cómo futuras soberanías pueden construirse literalmente a través de infraestructuras energéticas específicas. El artículo sigue la controversia aparecida en torno a la propuesta de una central eléctrica a carbón llamada "Desert rock", situando este proyecto fantasma dentro de una larga y duradera lucha en torno a la extracción de energía en tierras del pueble Navajo con la finalidad de iluminar su controvertido futuro. En su sentido amplio, estas resignificaciones de la soberanía apuntan hacia una modalidad diferente de acción medioambiental que sugiere que hay también otras relaciones en juego, confrontando las asunciones hechas tanto por adversarios como por aliados de que la política de protesta de (en este caso) las tecnologías del carbón es una práctica con ética auto-evidente.

Para intervenir en estos amplios debates, propongo que hay múltiples panoramas de poder en territorio Navajo, los cuales deben tenerse en cuenta en los actuales y urgentes debates sobre cómo la nación Navajo puede desarrollar una política energética más sostenible para el futuro.

Palabras clave: ecología política, soberanía, Navajo, medio ambiente, ética, territorio, práctica, sostenibilidad, panoramas de poder.

\section{Introduction}

Unlike ever before, environmental activists and organizations are among the greatest threat to tribal sovereignty, tribal self-determination, and our quest for independence. (Former Navajo Nation President Joe Shirley, Jr.)

Navajo (Diné) ${ }^{2}$ territory, located in the American Southwest, boasts some of North America's richest energy resources, including oil (the cause for the formation of the modern Navajo Nation in the 1920s); vast deposits of uranium ore (mined to build the U.S. Cold War arsenal of nuclear weapons); top notch wind and solar power capabilities (under development by NGOs, entrepreneurs, and the tribe since the 1980s), and some of the most easily accessible beds of low-sulfur coal, on both the eastern and western sides of the reservation. Since the 1960s, the mining and export of these coal reserves has built the formal economy of the Navajo Nation, making it infamous for its intensive and increasingly controversial reliance upon exporting carbon resources as the backbone of its economic development pathway. Coterminous with extraction, this same landscape boasts striking topography: its purple and red mesas, gaping canyons, red lakes, and soaring volcanic rock formations are now transnational icons of an exotic American West. In these registers that are simultaneously material and symbolic, Diné peoples' lived experiences of this energetic landscape are complex and vital, in the sense that vitality is about that which is necessary for life itself (in Latin, vitalis). How to sustain Diné life (as a political identity and cultural practice) amidst the everyday and broader, structural violence of settler colonialism is a question deeply embedded in the material past and material future of this particular territory. Yet even as tribal members debate different, even opposing visions of development for ensuring Hózhó (holistic well-being, tied to place), most agree that shared in common is this unique and storied geography, a place where deities, monsters - and their slayers - inscribed foundations for ethical action and wellbeing into the landscape itself.

A recently proposed development project has brought these apparent contradictions of place to the fore. In 2003, the Navajo Tribal Council announced a decision to construct the Desert Rock Energy Project ('Desert Rock'), a 1,500-megawatt coal fired power plant slated for the northeastern edge of the reservation

\footnotetext{
${ }^{2}$ Following nomenclature established in the Navajo Nation Code, I use the term 'Navajo' to refer to the name the tribe gives itself, 'Navajo Nation', thus distinguishing this political apparatus from the 'Diné' as a people. In practice among tribal members, 'Diné' and 'Navajo' are used interchangeably to describe themselves, so I follow suit in this article when referring to the people and territory in which the reservation is located.
} 
territory, near the Diné village of Burnham, New Mexico. Given the Nation's history of intensive resource extraction - critiqued as 'neocolonial' at least since (former) Navajo Chairman Peter MacDonald's 1960s attack on the profiteering of energy corporations' mining Navajo coal for off-reservation urban growth Desert Rock appeared to pose a challenge to such longstanding, settler colonial economics: this time, the Navajo Nation would enter into a joint venture with an energy company and its financiers, while maintaining control of the project and moving towards majority ownership. But, the proposed power plant ignited enduring grassroots and government struggles over tribal energy development practices and impacts on the sustainability of Diné territory into the future: a central question of tribal sovereignty. More than a decade later, the contested delay of Desert Rock creates an opening for seeing the effects of this proposed coal plant as a failed infrastructure project. Debates surrounding Desert Rock force a rethinking of the politics of environmentalism and autonomy, or sovereignty, as experienced by tribal members and leaders intimately invested in re-engineering the energy future of the Navajo Nation.

In this article, I argue that this decade-long, intense debate over Desert Rock has not only reopened a longstanding environmental conflict, but it has also provoked new articulations of sovereignty for Diné people engaged in energy debates. This provocation has occurred through a kind of embodied, territorial sovereignty, grounded in a historically particular place, which is simultaneously "a world of relational movements and countermovements" (Byrd 2011: xvi). In other words, I want to suggest that exclusively situating sovereignty within a legal-juridical framework elides embodied valences of sovereignty and the politics of indigeneity. Emphasizing sovereignty as lived, territorial, grounded and in motion exceeds more established formulations of sovereignty, through juridical and political-geographic frameworks - yet without rejecting them. ${ }^{3}$ That is, while conventional (and crucial) tribal-federal negotiations over policy and regulatory processes in major environmental projects on trust land importantly expose the broader "colonial entanglements" (Dennison 2013) in which the Navajo Nation finds itself, a critical ethnographic approach to the political ecology of Diné sovereignty suggests that Diné peoples' historic relationships with a homeland landscape - whether dwelling there, or transiting and migrating through or beyond that place - pose important challenges to strictly legal or juridical interpretations of sovereignty as the supreme authority of a state to self-govern.

Recent moves in political ecology, anthropology, and critical Native American/Indigenous studies (NAIS) are instructive here and deserve to be brought into orbit with one another. Some seek to rethink sovereignty in ways that challenge state-centric analyses, through support to global peasant and food sovereignty movements that challenge official discourses of food 'security' (Desmarais 2007); others consider 'graduated sovereignty' among Asian states (Ong 2006) and the insidious reincorporation of 'indigenous knowledge' by states involved in mapping and other territorial projects. These advance state authority (McCreary and Lamb 2014). Nonetheless, the primary emphasis in most approaches to natural resource and environmental governance is the jurisdiction of the (settler) state. Often, this "cunning of recognition" (Povenelli 2002) in fact reflects what Jean Dennison describes as a settler colonial "logic of recognition" (Dennison 2014). In her work on her own Osage Nation's shifting citizenship policies, Dennison details ethnographically how this problematic logic dangerously shifts discourses of belonging and selfidentification away from territory (quite literally, the very ground on which the future is to be built), favoring instead discourses of the body. With this shift, struggles to define citizen-selves through race, blood, and descent alone work to undermine indigenous nations' precarious relations with non-indigenous populations in shared or overlapping territories, and ultimately, Native nations' authority over their own land (Dennison 2014). I argue, with Dennison, that the politics of abandoning territorial notions of citizenship/sovereignty is part and parcel of settler colonial logics, creating the conditions for further erosion of indigenous authority over landscapes. And yet, as I have found over the course of several years of research with and among Diné people, there is a felt, lived, sensorial connection forged through practice between bodies and territories on the Navajo Nation - so much so, that I emphasize here the lived dimension of territorial sovereignty. The embodiment is closer to Tim Ingold's discussion of dwelling and enskillment as part of belonging to a territory (Ingold 2011), a phenomenological departure from what Dennison critiques as the more commodified, and ultimately divisive, identifiers of race, blood, and descent.

\footnotetext{
${ }^{3}$ As many American Indian studies scholars have argued, the established formulations of Federal Indian Law are themselves so deeply contradictory and "haphazard" that the field constitutes a sort of "legal wonderland" (Wilkins 2003, Wilkins and Lomawaima 2001, Deloria and Lytle 1983).
} 
With this argument, I engage with others already deeply involved in rethinking sovereignty, hoping that I might urge political ecologists toward critical ethnographies of settler colonialism's effects on indigenous territories as places whose futures are uncertain, and where complex articulations between embattled ecologies and American Indian tribal sovereignty pose peculiar challenges. Recent work in NAIS has shown the limits for North America of European social theories of sovereignty, by "indigenizing Agamben" (Rifkin 2009), arguing for tribal sovereignty as a "third space" in the United States (Bruyneel 2007), and rejecting approaches (even those that exist within Native communities) that treat sovereignty as a commodity or resource (Parker 2014). Instead, NAIS scholars argue that sovereignty is a "process" (Lambert 2007): it is "an act of interpretation" and a "methodological cornerstone" (Byrd 2011). Following this theoretical move, my research suggests that a kind of lived, territorial sovereignty is central in the interpretive work of Diné people engaged in energy debates.

As the struggle surrounding Desert Rock demonstrates, the ethical commitments at stake for Diné tribal members supporting and opposing Desert Rock exceed the scope of environmental politics as generally understood in the usual scripts of 'economy versus the environment' polemics - a discursive repertoire and politics that I challenge, along with others working in the overlapping arenas of political ecology, engaged anthropology/geography, and environmental justice (see Auyero and Swistun 2009; Burke and Shear 2014; Gibson-Graham 2006; Osterweil 2013 and Scott 2010, among others). I trace this lived, territorial sovereignty primarily through the social movement and knowledge work of Diné energy activists (including grassroots activists and tribal officials), engaging in determining future energy pathways for the Navajo Nation. This shift expands our notion of what politics is and might yet become, moving beyond contestational and juridical formations and into a realm where sovereignty and environmentalism are not always the primary positions of cultural critique. Especially when social movements are considered as significant actors in the realm of knowledge production, we gain a more expansive perspective on what sovereignty and environmentalism might mean in contemporary indigenous politics (see Carroll forthcoming; Casás-Cortes, Osterweil and Powell 2008, 2013). I explore how grassroots environmental justice groups on the Navajo Nation see their opposition to Desert Rock as a way of promoting, not undermining, tribal sovereignty, as Joe Shirley's quotation at the opening of this paper suggests. However, what sovereignty means to many tribal members challenges the authority often granted to the domain of juridical politics. This representational challenge helps us see other modes of struggle emerging and their attending ethics and practices for re-engineering the future of Diné landscapes.

\section{Landscapes of power}

The Desert Rock Energy Project made substantial promises. Project developers Sithe Global Power and the tribe's own Diné Power Authority (collaborating as the Desert Rock Energy Project, LLC) assured Diné tribal members and investors (The Blackstone Group) that the plant would be built by 2005, just two years following its public announcement. Desert Rock promised 1,200-1,500 construction jobs, which would end after five years, and 400 permanent plant operations jobs. Tribal revenue from Desert Rock was projected at US\$50 million annually, including the lease for the land, a fee for the water, and taxes and royalties to be paid to the Navajo Nation by Sithe Global. This is a significant sum for one power plant when compared with overall current revenue sources for the Nation. For instance, in 2008, the Navajo Nation produced 19.23 million tons (17.45 million tonnes) of coal overall, bringing in revenue of US\$58.91 million.

Despite the project's potential economic contributions, Desert Rock became increasingly controversial among tribal members and residents of the greater region. First, the economic benefits to the Nation were questioned: as critics of the plant were quick to note, the Nation would incur significant financial liabilities, including the possibility of federal carbon taxes, and other financial risks of long-term ownership. Second, none of the construction or management jobs were completely guaranteed to tribal members, despite a tribal law that calls for 'preference' in employing Diné people for on-reservation development projects. Third, and more importantly, opponents of Desert Rock resisted the project on grounds of environmental justice, pointing out the disproportionate siting of energy production facilities among an already "disproportionately impacted population" (US EPA 2010). Public health and environmental contamination from the plant's projected emissions of sulfur dioxide, mercury, and carbon dioxide in a landscape already defined by existing coal, oil, and uranium extraction posed an unacceptable level of risk, according to tribal and regional activists. Desert Rock would become the third large-scale coal fired power plant within a 30 mile (48 km) 
radius, with a fourth coal fired power plant 100 miles $(161 \mathrm{~km})$ to the west, all of which export power to Southwestern cities like Los Angeles, Phoenix, and Las Vegas, while 40\% of Navajo homes remain without electricity and nearly as many without running water. Tribal members and other residents of the region are quick to point out the known negative impacts of coal combustion on air quality, arguing that despite the developers' claims to state of the art 'clean coal' and carbon capture retrofit technologies, Desert Rock would skyrocket the pollution levels in a region already burdened by excessive ozone levels and a persistent yellow haze.

For the Navajo Nation leadership, building this power plant is not only about economic development for a population with a per capita income of just over US\$7,000, but is an exercise of the Nation's sovereign rights to use Navajo land and mineral resources as they see fit for the future of the Nation. For environmental activists opposing Desert Rock, this is a struggle over preserving a way of life, a distinct cultural identity and and ecological landscape, and it is about articulating an ethics of development that follows the principles of Navajo Fundamental Law, the customary code of ethics based in Navajo creation stories.

Reasons for Desert Rock's delay are complex. Federal regulatory requirements, resistance from Diné and regional environmental movements, challenges by the state of New Mexico, changes in tribal government leadership, the lingering effects of the 2008 economic downturn, and investments in new coal power becoming increasingly suspect and risky, have all cast a shadow over Desert Rock's promise. A Sithe Global project manager reported that most coal plants of this scale are built in under a year, but with Desert Rock, the company's first project on tribal territory, the only infrastructure on site is a well pad to test the aquifer level, storage barrels, hoses, and a few industry trailers encircled by a chain link fence. Metal cisterns marked 'for livestock only' (transformed by colorful graffiti into objects of art) sit in the distance, providing a dubious water source for local herds of sheep. Desert Rock became a test of tribal sovereignty, but not only in its ability to challenge federal and state (of New Mexico) policies. Rather, even in its ambiguous state of being, Desert Rock tested and transformed other valences of tribal sovereignty among tribal members themselves, promoting a vigorous discussion about what kinds of infrastructure might constitute a more selfreliant, financially and politically autonomous future.

This landscapes of power approach helps us engage landscapes as the ongoing, intertwined coproduction of human and non-human worlds, and sees power as material, semiotic, and cosmological. Similar to Donald Moore's suggestion that landscapes are "entanglements" of race, colonialism, and sovereignty, made meaningful through "suffering" (Moore 2005), landscapes of power emphasize articulations of difference and painful impacts of settler colonialism on Diné lands and bodies. With this approach, I join Moore and others in pushing "third generation political ecology" (Escobar 2010) beyond the postmodern action impasse, toward an analysis that considers meaning and interpretation as the theoretical grounds for the redesign that the present and future world demands.

In this way, landscapes of power encourages rethinking "ecological distribution conflicts" (MartinezAlier 2005) as always, and perhaps fundamentally, sociocultural and cosmological conflicts, with moral concerns over what is good and bad, right and wrong. As Keith Basso has shown, landscapes oftentimes 'stalk' their inhabitants, and far from being an inert backdrop to human action, landscapes are named, narrated, and known in ways that transmit tales of the way we ought to live now and into the future (Basso 1996). On the Diné Nation, coalmines, existing and proposed power plants, wind and solar projects, and the mountains that define Navajo landscapes of power all do this - yet, tales of how we ought to live are still being written, with their endings uncertain. This tension between what is and what might be, between language and things, is part of what structures the debate over tribal energy development. Such are the shifting landscapes of power in this study of Desert Rock, shaping meanings and imaginations of what sovereignty is and might be, as a lived experience. That is, sovereignty is not just situated in Western law, but in other places, practices, and politics as well.

Although early political ecology (see Biersack 2006; Blaikie and Brookfield 1987; Robbins 2004) importantly introduced an ecological dimension to political economic analyses of land use struggles, much remains to be done to critically understand the ways that contested meanings and materialities shape humanenvironment relationships and emerging political imaginaries in situations of settler colonialism. Settler colonialism in the U.S. and other similar settler societies is a particular historical configuration wherein "the process of conquest has been neither completed nor abandoned" (Dennison 2012: 6). Importantly, the primary target in this process of conquest is for the settling power to gain access to land that is historically 
and presently under indigenous control (Ibid.). Given the urgent need to defend indigenously controlled territories, there remains a need to push political ecology toward deeper analysis of historic and ongoing coloniality and difference within settler societies (Escobar 2008; Middleton 2010). On the Navajo Nation, because 'the environment' has proved conceptually inadequate for capturing the complex stakes and dimensions of the Desert Rock struggle, the landscape of power framework is helpful for grounding us in a historically, culturally, and ecologically specific landscape: Diné Bikeyah, Navajo territory. It is useful, as well, for expanding our analytic awareness to include critical aspects of the conflict. In particular, I argue that current contestations over the future of the Diné landscape - when examined through a study of the landscapes of power involving the Desert Rock Energy Project - reveal that diverse and multiple interpretations of tribal sovereignty are being deployed, vis-à-vis the energy infrastructure.

Infrastructure is, of course, a question of what kinds of worlds we desire to build, embodying values, making the mundane visible, illuminating existing connections and forging new ones. This article proposes that on the Diné Nation, competing deployments of sovereignty and environmentalism - as well as their entanglements - depend upon energy infrastructure. As "movable emblems of imaginable social orders" (Naor 2014), infrastructural projects such as Desert Rock work to position different possible futures: in Navajo energy politics, coal, wind, solar and uranium are each emblematic of particular social orders, desired by some, decried by others.

The texture and durability of energy infrastructures materializes sovereignty. Coal plants like Desert Rock, abandoned tailings piles from the 1950s uranium boom, anemometers erected to measure wind speed, and scattered solar photovoltaic panels are part of the landscape of the Navajo Nation today, their undeniable materiality a reminder that at stake in this debate over the future is how we might re-engineer nature itself such that the line between nature and infrastructure becomes blurred (Carse 2013). And in this blurry, liminal space lies sovereignty, contested not only in courts of law (though legal contestations are of course, crucial) but contested on the ground itself, through the various infrastructures that generate power, immanent and particular to this terroir. ${ }^{4}$ In this sense, the mountains that Diné people hold sacred are part of an infrastructural world defining the space of Diné sovereignty: mountains, not only coal plants, organize social life. The four sacred mountains, it could be argued, are the original infrastructure of Diné identity, territorial struggle, and sovereignty, and remain the geopolitical and geo-cosmological touchstones for orienting oneself in the Diné universe. Later in this article, I quote a Diné elder speaking about the original ethics or 'fundamental law' of the Diné as law that emerges directly from these mountains: the land itself generates a certain politics of being. For many Navajo people, to live close to the land - quite literally, to live and garden and herd sheep on the territory defined by these mountains - continues to carry with it a tremendous amount of social and cultural power, cutting across generational, linguistic, and occupational divisions. The infrastructural world of the Diné affects alternative notions of sovereignty not through the sedimentation or fixing of things, so much as through seeing these mountains as points of orientation in these other forms of law and politics (see de la Cadena 2010).

There is of course a large body of work in environmental policy, Federal Indian Law, and legal anthropology informing the more juridical-oriented debates surrounding federal primacy, domestic dependence, and the political sovereignty of Native and First Nations in the U.S. and Canada. As I have argued elsewhere, there is an intimate connection between debates over Navajo tribal governance and debates over natural resource management (Powell and Curley 2009). The materiality of the Nation - that is, the land itself and the diverse forms of life it supports - is the currency in play when Navajo tribal members openly critique and debate the model of governance the Nation 'ought' to have. There is also a vast literature addressing sovereignty in the field of critical indigenous studies, where scholars assert that sovereignty is "ambiguous" (Wilkins 2003; Wilkins and Lomawaima 2001), geographically "imagined" (Biolsi 2005), a "third space" in settler societies (Bruyneel 2007), or "an ongoing process of negotiation" and "a landscape of multiple, overlapping, and competing sovereignties" (Lambert 2007: 211). Or as Mark Rifkin reworks Giorgio Agamben's theory of sovereignty: the "narration of Native peoples as an exception from the regular categories of U.S. law" reveals this "inclusive exclusion" of American Indians (Rifkin 2009: 90).

\footnotetext{
${ }^{4}$ I am grateful to colleagues at the 2014 Infrastructural Worlds Conference at Duke University in Durham, North Carolina, for helping me think through some of these dimensions on Diné territory, including Ashley Carse, Stephanie Friede, Diane Nelson, Nick Shapiro, and Kirk Jalbert, among others.
} 
This makes sovereignty an "enveloping yet empty sign" for American Indians that legitimates state violence through the very "peculiar" and "anomalous" role that Native peoples occupy within U.S. law (Rifkin 2009: 115). And yet, while Rifkin's reading of the uniqueness of American Indians forces a critical rethinking of the disjuncture of U.S. jurisdiction, the analysis does not move us beyond the dominance of the state. Much more work is needed in anthropological and ethnographic approaches to sovereignty to explore how sovereignty is meaningful in trans-juridical arenas of discourse and practice. This article's aim, in part, is to contribute to this trans-juridical discussion of contemporary interpretations of sovereignty, vis-à-vis energy infrastructure.

For many Diné people, sovereignty is defined through a strong attachment to a particular territory. The four mountains signal this political cartography (the customary homeland that the Diné recognize, and the approximate legal boundaries of the contemporary reservation ${ }^{5}$ ), with another two sacred mountains anchoring the interior of Diné homeland. The historically and culturally particular importance of this mountainous orientation for Diné people has been widely discussed and documented (Iverson 2002; Kelley and Francis 1994; Sherry 2002). As any amateur internet search reveals, almost all visual maps of Navajo territory, or Dinetah, define the Nation in spatial relation to these mountains. Navajo and non-Navajo mapmakers consistently emphasize the four cardinal mountains (and frequently, their attending sacred colors) as much as, or even more than, they emphasize the overlapping state jurisdictions of the four corners states of New Mexico, Arizona, Utah and Colorado. This spatial politics is also inscribed in the tribe's own Great Seal of the Navajo Nation (Figure 1), in which the four sacred mountains surround livestock (horse, cow, and sheep), are bolstered by two leafy cornstalks (simulacra of Diné corn pollen cosmology and the Creation story), and ultimately encircled by a rainbow, signifying the historic journey of Diné deities.

Sis Naajiní (Blanca Peak) is to the east, Tsoodził (Mount Taylor) to the south, Dook'o'oosłííd (San Francisco Peaks) to the West, and Dibé Nitsaa (Hesperus Peak) to the north. In stories of the sacred landscape and also depicted in most maps, there are also two sacred mountains in the interior of Navajo country: Dził Ná'oodiłii (Huerfano Mountain) and Ch'óol'í'í (Gobernador Knob). Each is associated with a precious material (white shell, turquoise, abalone, obsidian, fabrics, and jewels, respectively) and a particular color (shown in the Great Seal). Despite diverse contemporary religious commitments among Diné people, ranging from Catholicism to Native American Church, Corn Pollen Way to Pentecostalism, these mountains still have historical, cultural and cosmological significance. Diné poet George Blueeyes expressed the vitality of the territorial relationship this way:

These mountains and the land between them

Are the only things that keep us strong.

From them, and because of them we prosper.

It is because of them that we eat plants and good meat ... (Blueeyes 1982: 2)

The significance and power of the Navajo landscape is also expressed through the collective, historical memory of many Diné elders. Many recall their grandparents' stories of the U.S. government's war against the Navajo, resulting in the 'Long Walk' of 1864-1868 when the U.S. military incarcerated the majority of the Navajo population at Bosque Redondo (Fort Sumner) in New Mexico territory. In 1868, with the signing of the first treaty between the Diné and the U.S. government, remaining survivors were released from imprisonment and permitted to walk home, returning to their territory within the four sacred mountains. This cosmological cartography is also an ethical cartography: each mountain - with its associated direction, stone, and set of stories - instructs the 'five-fingered beings' in proper conduct, how to control the flow of life (iina), and how to exist in dense networks of human and non-human relationality ( $k$ 'e). Far from static, this landscape is vibrant and contested: over the past few years, the Navajo Nation has allied with neighboring Pueblo and Apache Nations who also regard these mountains as sacred, striving to block development

\footnotetext{
${ }^{5}$ The original Navajo reservation, established in 1868 as part of the treaty that enabled Diné people imprisoned at Fort Sumner (New Mexico) to return to their homeland, was situated more directly south of Mt. Hesperus (the sacred mountain to the north) and more eastward. Through various annexations the reservation's legal boundaries expanded westward until the 1930 s.
} 
projects such as the Arizona Ski Bowl resort on the San Francisco Peaks and the re-opening of uranium mines on Mount Taylor.

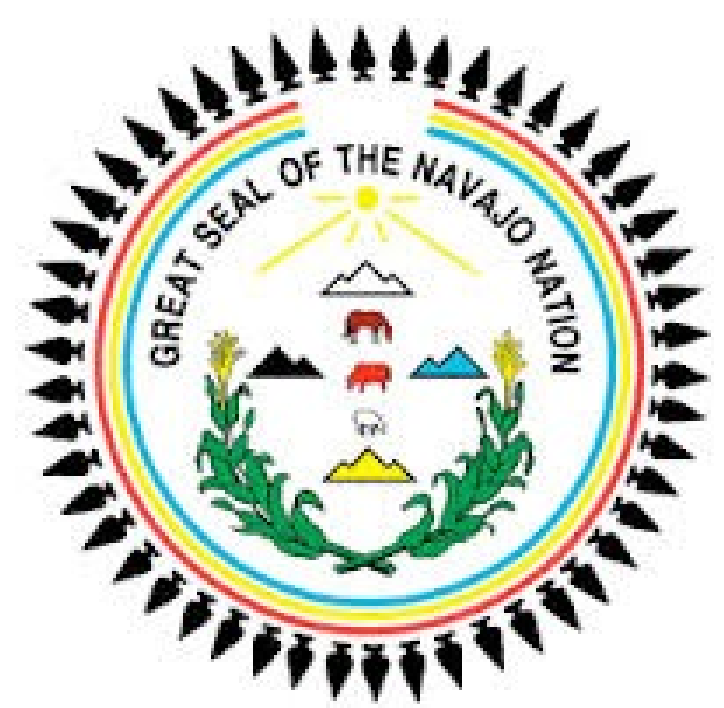

Figure 1: Great Seal of the Navajo Nation. Source: Navajo Nation.

This vital geography illustrates a sense of lived, territorial sovereignty rooted in a historically, culturally, and ecologically specific place. Sovereignty is inscribed in these four mountains and also in the rainbow that holds them together, in this particular 'environment', although the deployment of this term in this way fails to capture the sense of place that is at stake. We see the rainbow depicted in official imagery, as in the Great Seal, because of its history as a crucial pathway in Diné cosmology and law. The rainbow is entangled with Diné epistemology, grounded in a particular place: it is said that Talking God, one of the original Diné Holy People, used the power of a sacred rainbow on which he traveled to create language for the earth-surface people (Aronilth 1992: 49). "The rainbow is our sovereignty," argued a tribal member at a recent meeting on the future of Diné energy policy, invoking what she and others consider to be a "teaching of the elders." 6 This sense of emplaced sovereignty speaks to a sense of epistemic and cosmological difference, given the primacy accorded to Navajo Fundamental Law and its teachings, which includes creation stories that convey the significance and power of these four mountains and the rainbow. In contrast to the juridical, legalistic interpretations of sovereignty deployed by politicians and legal scholars, this alternative interpretation of sovereignty rests upon an understanding of the 'environment' - or place, more precisely - that recognizes but is not contained by discussions of air and water permits or negotiations of federal primacy (see Powell and Long 2010). It recognizes other landscapes of power constituting the Navajo Nation.

Although the struggle over Desert Rock has been widely portrayed by the media as the conventional script of jobs-versus-environment, there are deeper stakes. As a way of engaging the sociocultural politics of energy on Native lands, landscapes of power offers a framework for understanding the materiality and figurative nature of contentious energy development projects, situated in specific places with their own, and often competing, cultural histories and uncertain futures. Methodologically, the approach also offers ethnographic understanding of energy development in Native American communities. That is, the ways in which energy extraction is remembered, imagined, deployed, assembled and felt 'on the ground' by people impacted by policy decisions. This is the central and driving concern for research and action.

\section{Diné energy legacies}

\footnotetext{
${ }^{6}$ Janene Yazzie, meeting on the future of Navajo energy, Albuquerque, NM, April 12, 2014.
} 
The Navajo Nation is located in the chaparral flora and alpine forests of high desert badlands and contrastingly low canyon lands of the Colorado Plateau in the Southwestern United States, crossing the state borders of Arizona, New Mexico, and Utah. The current reservation's land base is 27,000 square miles (about $70,000 \mathrm{~km}^{2}$ ), making it the largest federally-recognized Native land base in the U.S. Unlike many American Indian Nations, the Navajo reservation, secured through several treaties with the U.S. government beginning in 1868, is roughly contiguous with the Navajo homeland prior to colonization. Enrolled members of the Nation number just over 300,000, with $60 \%$ of members living on Navajo territory. Today, the tribal government mirrors the U.S. federal government, with executive, judicial, and legislative branches representing the reservation's 110 chapters, or local municipalities. However, the appropriateness of a centralized, three-branch system is increasingly an area of heated debate among tribal members, a great majority of whom express deep skepticism and mistrust of the government in the Nation's capital of Window Rock, Arizona. Discontent often follows the usual critical script of government mismanagement, misspending, misplaced development aims, and overall distance from the people it is supposed to serve. But the specific entanglements of Navajo governance with the Navajo energy landscape situate contemporary calls for government reform into historical legacies of natural resource extraction that profoundly shape current understandings of governance, sovereignty, and the environment.

Historically, Navajo territory has been defined by energy development and settler-colonial expansion so much so that the present infrastructure of the Nation is largely the infrastructure of energy. As John Redhouse reveals, the Treaty of 1868 between the Diné people and the United States released Diné people from incarceration at Bosque Redondo (Fort Sumner) and established a reservation, as is widely remembered today; however, this political land enclosure enabled the U.S. to secure a right of passage for railroads to pass through former (though not reservation) Navajo territory (Redhouse forthcoming: 6). The Treaty contained language stipulating that Navajos would not create any "opposition to the construction of railroads now being built or hereafter to be built, across the continent" (Ibid.). Then, in the early 1920s, federal surveyors discovered oil in the Hogback/San Juan region of northern New Mexico (just outside present-day Farmington, NM), finding that territories once considered hinterlands by east coast policymakers were in fact hugely rich in mineral deposits. This discovery prompted negotiations between oil companies, Navajo traditional leaders, and the U.S. Commissioner of Indian Affairs, who assisted the companies in their fervent quest to secure leases to the rich, untapped oil reserves (Chamberlain 2000; Iverson and Roessel 2002; Needham forthcoming). In 1923, the Standard Oil Company signed an oil lease with a small group of Navajo men. This contract foreshadowed the federal policy aimed at the 'reorganization' of customary Native leadership structures and the establishment of official 'tribal councils' as recognized governing institutions in the following decade (Grossman 1995). However, in the eyes of federal agents, the negotiating process lacked clear representation on the part of the Navajos, who had no centralized governing body and instead followed customary practices of organizing small, regional councils to respond - often in contradictory ways - to the oil companies' requests. Notably, many of these regional councils rejected the companies' early incursions and proposals. In the eyes of Washington this confusion, combined with the growing drive for energy resources, produced the need for a systematic tribal government able to sign contracts with external developers. So following the Standard Oil Company transaction, the federal government affirmed a small group of leaders as the authoritative representatives of the Navajo Nation. Energy interests in the Navajo landscape were, by all accounts, at the center of the production of the Nation as a recognizable, unified political body.

A decade later, federal agents mandated a calculated livestock reduction among Navajo herders, revealing another energy story. In the name of tackling overgrazing and its impacts on regional development, federal agents decimated entire herds of Navajo sheep, crippling Navajo families. The government's alleged fear was that topsoil erosion into nearby Lake Mead would impede the generating capacity of the Hoover Dam, which in 1931 was the world's largest hydroelectric power generating facility. Moreover, as signifiers of Navajo identity, sheep literally embodied energy- through their flesh as sustenance, their wool as warmth, and the practice of herding as a central livelihood activity. The political ecology of livestock reduction and the near destruction of a way of life was, in the end, intimately tied to power generation for the growing urban Southwest.

However, it was not only the urban 'Sunbelt' that demanded Navajo electricity: even before Arizona and New Mexico's post-war boom, Navajo mines and Navajo labor were supplying rich reserves of uranium 
to the U.S. government (the sole buyer, by law) for the budding nuclear weapons technology that would become the U.S. material stockpile supporting the country's status as an emerging global power. From the 1940s - 1990s, uranium was mined extensively on tribal lands, driven first by the race for the atom bomb at the end of World War II and then the Cold War arms race and rapid buildup of the U.S. nuclear arsenal. ${ }^{7}$ Federal commissions tellingly categorized the U.S. Southwest as a 'national sacrifice area' for all of the uranium mining and weapons testing that went on in the name of national security. Navajo landscapes and bodies remain scarred with these memories, with dozens of un-reclaimed uranium tailings piles contaminating drinking water and some families unknowingly using radioactive stones from former mines to build their homes. The ongoing health effects (primarily cancers) are material reminders of the coloniality of power at work on the Navajo Nation. In Joseph Masco's terms, this is the "nuclear uncanny" in the U.S. Southwest: the strange and persistent possibility that radioactivity permeates all aspects of the environment and everyday life (Masco 2006). In response to this painful legacy of uranium extraction, the Navajo Nation Tribal Council in 2005 passed the Diné Natural Resources Protection Act, calling the history of uranium mining "genocidal" and placing a moratorium on any future uranium mining on reservation land.

Yet, the mid-century boom, bust and more recent ban of uranium mining is not the story of coal mining on the reservation. From the 1960s onward, the Navajo Nation has sold its rich reserves of coal offreservation to regional utility companies, which in turn produce electrical power for urban consumption. In 1952, a survey by the Arizona School of Mines showed that Navajo land contained expansive reserves of strippable coal, lying within 4-8 feet (1-2.5 meters) below the surface; recent estimates place Navajo coal reserves at between 2.5 to 5 billion tons (2.3-4.5 tonnes). This discovery inspired the U.S.'s growing energy industry to establish mines on the reservation, with Peabody Coal Company opening mines in the western region of the reservation atop a formation known as Black Mesa, called 'Black' because of its visible coal seams. In 1957, the area of the current proposed Desert Rock plant was leased for coal mining for the future Four Corners Power Plant, digging the foundation and then expanding in subsequent decades to become what is now the 33,000-acre (13,350-hectare) Navajo Coal Mine, the feeder mine for Desert Rock. In the 1960s, two large-scale coal fired power plants were built near the Navajo Nation's northeastern border: the San Juan Generating Station and the Four Corners Power Plant, the latter more recently achieving infamy as the largest source of nitrogen oxides in the United States. ${ }^{8}$ In the early 1970s, a third power plant, the Navajo Generating Station, was constructed near Page, Arizona, completing this triad of large-scale (greater than 2,250 megawatts each) electrical generation facilities. These three existing plants - their proximity to one another and to the proposed Desert Rock site - figured centrally in the debate over Desert Rock.

With oil as the most lucrative resource early on, the Navajo Nation began to profit from bonuses, rent and royalty payments from the mining corporations, earning US\$76.5 million by the early 1960s. Leaning on the 1938 Indian Minerals Leasing Act (IMLA) for legal support, the Nation was able to lease 'unallotted lands' for oil wells to more than a dozen energy development companies. ${ }^{9}$ Although intricate legal and business procedures governed by the IMLA purported to grant greater self-determination to Navajo leaders, complexities of the leasing process resulted in the reverse in practice, marginalizing tribal decision-makers in land-use negotiations. For instance, relative to fair market values, the Navajo Nation received meager royalty payments for its mineral resources and did not meaningfully participate in the actual business management of energy development. Corporations like Standard Oil and Peabody Coal held the reins on these lease agreements and set royalty payment fee schedules that did not increase with inflation, across several decades. In sum, the tribal government received minimal revenues for its resources and had little authority or agency in the processes of contract negotiation over its mineral wealth.

\footnotetext{
${ }^{7}$ See Brugge, Benally, and Yazzie-Lewis 2006; Johnston, Dawson and Madsen 2010; Masco 2006, and Pasternak 2010.

${ }^{8}$ The Four Corners Power Plant emits 45,000 tons (40,800 tonnes) of nitrogen oxides annually (U.S. EPA). The U.S. EPA has proposed requiring pollution controls on the FCPP by requiring the facility be retrofitted with Selective Catalytic Reduction on all of the Plant's five units. This meets the U.S.'s Clean Air Act requirements targeting all older coal-fired power plants in the U.S. with Best Available Retrofit Technology. Should this reduction go through at the FCPP, it would amount to a 36,000-ton (32,658 tonnes) reduction, or the equivalent of taking half of all Arizona's gasoline-burning cars and trucks off the roads. Source: U.S. EPA Press Release, October 6, 2010.

${ }^{9}$ Dawes General Allotment Act of 1887 (amended twice and remained in effect until 1934). The Act provided for the division of tribally held lands into individually-owned parcels and opening "surplus" lands to settlement by nonIndians and development by railroads.
} 


\section{Practicing extractivism}

Elected and community-based leaders recognized the exploitative, extractive nature of these relationships with energy companies and, in the 1960s, started pushing back using direct action and coalitionbuilding strategies. Energy emerged as a new mode of Navajo nationalism and the exercise of tribal sovereignty, transforming the political- ecological terrain of development politics on Diné land. In the 1960s, local residents of Burnham, New Mexico - the proposed site of the Desert Rock Energy Project - along with a broader coalition of youth activists successfully mobilized to stop proposals for new coal gasification facilities in Burnham. Influenced by recent decolonization movements in Africa, recent world systems theories, and the growing American Indian Movement, these activists developed a critique of colonialism that situated energy development as underdevelopment for the Navajo Nation, launching a critique of neocolonialism that persists in this community today (Needham 2010, 2014). Activists occupied one of the mines on Black Mesa in the west and staged an armed occupation of a semiconductor plant in the reservation town of Shiprock in the east, creating a reservation-wide movement of "anti-colonial populism." Crucially, this movement's theoretical grounding lay in defining Diné self-determination in terms of control over natural resources. As historian Andrew Needham shows, in the early 1970s, this social movement bolstered the political campaign of Navajo Chairman Peter MacDonald, who ran for office on a similar anti-colonial critique (Needham 2014). Yet, MacDonald wound up enraging the pan-Indian youth activists when, rather than ending extractive industry altogether as they demanded, he made it clear that the Navajo Nation wanted "a piece of the action" in energy projects (Needham 2010). MacDonald led a coalition of energy-rich tribes to form the Council of Energy Resource Tribes (CERT), modeling their alliance on the Middle East's Organization of Petroleum Exporting Countries (OPEC). Under MacDonald's leadership, CERT became a powerful broker of energy deals between tribes, the federal government, and corporations, gaining a respected place at negotiating tables in Washington, DC.

Among community-based energy activists, an incident in 1989 in the southwestern reservation community of Dilkon, Arizona invigorated the local and national grassroots movement for energy justice on tribal territory. This event, and its effects, demonstrated that CERT was not alone in redefining regional and national energy debates: Navajo non-governmental organizations were also transforming Navajo landscapes of power by emerging as defining social actors in indigenous environmental politics. In Dilkon, a group of neighbors, mostly relatives, successfully blocked a contract between Waste Tech, a biomedical waste storage company, and the tribal government, that would create a waste repository for refuse from West Coast hospitals in their community.

Community members made their case on the grounds of environmental racism and environmental justice, newly emerging discourses in U.S. environmental politics of the late 1980s (Cole and Foster 2001; Di Chiro 1996; Martinez-Alier et al. 2014.) They pointed to the potential environmental health impacts of the waste site as well as the disregard for Navajo taboos surrounding proper handling of death and body parts. The struggle attracted the attention of national media and indigenous leaders across the Western U.S., as they rejected the tribal government's proposal to place the facility in Dilkon - or anywhere on reservation land.

These neighbors organized themselves as Diné Citizens Against Ruining our Environment (Diné CARE) and helped launch a national pan-indigenous group, the Indigenous Environmental Network (IEN). Following their eventual success in defeating the Waste Tech proposal, Diné CARE was at the center of most of the environmental controversies on the Navajo Nation during the 1990s and 2000s. Diné CARE emerged as a leading critic, locally and nationally, of the impacts of radiation exposure on Navajo uranium miners, the over-harvesting of Navajo timber in the 1990s, and the health and environmental consequences of the Navajo Nation's ongoing financial dependence on coal resources, including the Desert Rock proposal (Powell and Long 2010; Sherry 2002).

At the same time all of this energy activism was building in the eastern territory of the reservation, other tribal environmental groups were busy organizing in the West to protect Black Mesa. In Diné cosmology, coal is the liver of the earth and Black Mesa is the female deity of the Navajo landscape. ${ }^{10}$ Situating their struggle as an issue of environmental justice and the protection of a sacred site, residents of the western region, working in coalition with groups like Diné CARE in the east, pressured the tribal

\footnotetext{
${ }^{10}$ Her male cohort is the Chuska Mountains, location of the controversial timber harvesting in the late 20 century (see Sherry 2002).
} 
government for closure of the Black Mesa mines. As a result of their vigorous organizing and legal challenges, operations at the largest of two mines at Black Mesa were suspended in 2005 when the regional power station fed by the mine (Mohave Generating Station in Nevada) was closed down. While the Kayenta Mine on Black Mesa continued to operate, activists deemed this partial closure a huge victory, despite the complicated impacts on tribal members' employment, as it halted the transport of coal via a 273 mile (439 $\mathrm{km})$ above-ground slurry pipeline, using pristine groundwater to move tons of coal from the mine to the generating station (Begaye 2006). Like many of these struggles, the victory was complicated - with many activists having family members who worked for the mine - these actions divided families, raised the persistent dilemma of jobs versus the environment, and yet launched these groups productively into an ongoing negotiation with the utility company, Southern California Edison, to help fund what activists envision as a 'just transition' from tribal reliance on fossil fuels to renewable energy, especially solar and wind power.

There are two reasons that make Desert Rock different from these previous struggles, and urgent and so controversial. First, widespread concerns over the role that coal plays in sustainable development and climate change have transformed the political climate of fossil fuels since the 1960s. Groups like Diné CARE interpolate and re-deploy these wider concerns, translating them into the Navajo language and the customary code of ethics known as Navajo Fundamental Law. Yet more significantly, with Desert Rock, the Navajo tribal government is initiating and asserting at least 50\% ownership in an energy project on reservation territory - a counter-move to the colonial conditions of extraction and exploitation that have largely dominated lease agreements since the 1920s. That is, through its joint venture with Sithe Global, the Navajo Nation government is in a sense actively assuming what used to be the outside developer's role. Leaders largely see such a move toward ownership as an enhancement of tribal sovereignty (following the example of CERT, for instance), while groups like Diné CARE tend to see such a move as an erosion of Diné sovereignty. They express concern over ambiguous liabilities for eventual carbon taxes, health and livelihood risks to be borne by local residents, and a misguided enthusiasm for energy minerals at a moment when translocal energy politics questions the security of coal as a long-term pathway. Through their efforts to re-direct the Nation's development agenda, grassroots organizations like Diné CARE have also been redefining meanings of environmentalism and sovereignty for the Navajo Nation.

Elsewhere in North America, other instances of large-scale energy development and waste management have also forged articulations between tribal sovereignty and energy debates, such as the bid by corporate conglomerate Private Fuel Storage to transport and store high-level nuclear waste to the reservation of the 100-member band of Skull Valley Goshutes in Utah (Ishiyama 2003; TallBear 2000); or the effect on the Yakama Nation's relationship with salmon and sturgeon due to a radioactive bleed from the Hanford nuclear production complex, located upriver on the Columbia River in Washington; or the history of Standard Oil's intervention in the Osage Nation (see Dennison 2012); or the ongoing battles over the tar sands and new oil pipelines in northern Alberta, Canada. Of course, all of these situations are distinct to the dynamics of each Nation's particular, and changing, landscapes of power.

The former President of the Navajo Nation, Joe Shirley, Jr. pursued Desert Rock as a central project of his two terms in office (2003-2011). In a statement to the press in late 2009, also quoted at the opening of this article, Shirley expressed a stark opinion regarding Desert Rock's delayed construction: "Unlike ever before, environmental activists and organizations are among the greatest threat to tribal sovereignty, tribal selfdetermination, and our quest for independence" (Shirley 2009). This statement - which circulated widely in print, on online blogs, and in conversation - worked to establish a distinct boundary between an imagined 'us' and 'them.' Yet, more importantly, the statement's discursive power located environmental politics as the enemy of Diné autonomy, when in fact, environmental politics has a longstanding role as constitutive of Navajo nation-building and self- determination, as discussed in the history above and enacted by a diverse group of Diné leaders, including those who formed CERT and Diné CARE.

Shirley's attack on environmentalists shows how the landscapes of power on the Navajo Nation have shifted: in his assessment, the enemy is no longer just outside energy corporations or the federal government, but it is civil society social movements which entangle and include his own tribal members. In effect, Shirley situates environmental sustainability as the enemy of sovereignty, arguing for political sustainability instead - a critical aspect of securing self-determination that is largely left out of widely circulating definitions of sustainability, centered on the 'three E's' or pillars, of sustainability: environment, economy, and equity. 
Shirley's challenge to environmentalists becomes more complicated in practice, however, when we learn that those posing the so-called 'greatest threat' are not so easily identified. Tribal members as well as non-Navajo activists constitute local and regional environmental organizations opposing Desert Rock. Similarly, Diné movements for tribal sovereignty - with their historical diversity - are supported by many of these same socalled environmentalists. Furthermore, many of these contemporary 'environmental activists' Shirley vilifies reject being labeled as environmentalists, and also the conventional eco-politics that such identification implies. Yet for contemporary leaders like Shirley, any rubric for sustainability is driven by the desire to ensure political autonomy into the future. In this sense, political ecological debates over sustainability in Native Nations are always, at the same time, debates over tribal sovereignty. Despite where one falls on the question of whether sound tribal economic development can occur through extractive industries, I would argue (with Shirley and with his opponents) for an urgent, epistemological and political corrective to official discourse in sustainability studies in the U.S. based on the 'three E' approach. That is, we must insist that environment, economy, and equity are incomplete without a consideration of sovereignty for Native Nations. And yet, sovereignty is not self-evident or stable, with multiple meanings given to autonomy and selfdetermination for tribal members.

\section{Rethinking sovereignty through ethical practice}

Environmental activists are well aware of the Navajo Nation's compromised position vis-à-vis federal authority in this contemporary moment of settler colonialism. In the Desert Rock proposal and other largescale energy and environmental projects, the Navajo Nation government has little control over federal environmental regulations and the various permits required by law for any large-scale development project to go forward on tribal land. This inescapable interdependence is part of the fabric of settler colonialism or, what Mark Rifkin calls an "enforced structural relation" (Rifkin 2009). On the Navajo Nation, this structural relation has been made visible historically in contested arenas of energy development. Environmentalists, or those whose actions are interpreted as such, emphasize the Nation's "quasi-sovereign status" ${ }^{11}$ through their work to make visible the complicated, bureaucratic procedures of approval managed by the United States Bureau of Indian Affairs. To be specific: Late 19th century treaties between Indian Nations and the U.S. government established that permanent homelands for Native peoples would be held "in trust" by the U.S., securing "federal primacy" over all Indian lands.

The federal government has attempted to control the environmental standards of Native lands over time, attempting to constrict tribal sovereignty in numerous ways, but in particular in regard to independent management of natural resources (Voggesser 2010). Native Nations cannot independently establish rules in environmental regulation and protection, even when they may have their own tribal environmental offices, like the Navajo Nation's Environmental Protection Agency (EPA). For instance, Native Nations can use their tribal EPA's to mandate higher, just not lower, environmental standards. Yet in this framework of 'federal primacy', Native Nations are purportedly 'treated as states' (TAS) by the U.S. through its agencies, granting tribes equal status as states in being subject to federal permitting processes and procedures. Environmental law scholars note this is largely understood as 'enhancing sovereignty' of Native Nations by limiting the role that surrounding states can play in tribal decision- making (Rosser 2010). Therefore, because Desert Rock is proposed for land held in trust by the U.S. - established during 19th century treaties - the federal government has an oversight role as part of its trust responsibility. Thus, the National Environmental Protection Act (NEPA) requires the project developers to obtain: a federal Clean Air Permit, a final Environmental Impact Statement, a Biological Opinion, and a Right of Way permit to develop the site. Most of these permits are entangled in litigation brought forward by activists or in the science of environmental health that does not bode well for Desert Rock. For instance, the Draft Biological Opinion found that the San Juan River, home to the already endangered Colorado Pikeminnow and Razorback Sucker, is already polluted beyond acceptable thresholds with mercury and selenium from the landscape's existing coal power complex.

On the Navajo Nation, sovereignty has been deployed vis-à-vis energy technology in the legal arena for some time, especially concerning the interests of corporations in extracting natural resources from Navajo

\footnotetext{
11 This is a phrase often used by critics and supporters of the tribal government. Earl Tulley, personal communication, June 29, 2008.
} 
lands. In 1985, Kerr-McGee v. Navajo Nation bolstered tribal sovereignty by confirming the Nation's authority to tax business activities on the reservation. ${ }^{12}$ The Kerr-McGee Corporation is a billion dollar energy corporation that led the way in uranium mining, oil, and gas exploration on Navajo territory (and in the greater Southwest) from the 1920s onward. Challenging the Nation's right to tax their mining activities, Kerr-McGee inadvertently opened the way for the recognition of tribal sovereignty by way of taxation. The Kerr-McGee case, along with similar legal challenges involving neighboring Native Nations, held that the "power to tax is an essential attribute of Indian sovereignty because it is a necessary instrument of selfgovernment and territorial management." ${ }^{13}$ Such legal precedent made it possible for Native Nations to exercise greater agency in negotiating leases with outside corporations for mineral extraction, suturing sovereignty to land use. Yet, Native Nations' own development projects - like Desert Rock - remain subject to federal regulations, requiring ongoing, difficult negotiation to determine how these regulations are enacted in practice.

As mundane as this discussion may appear, such tax law sets legal precedent for future deployments of tribal sovereignty, shaping how the Navajo Nation exercises its sovereignty in cultivating new business partnerships such as the Desert Rock Energy Project, marking an historic move away from the leasing contracts that dominated corporate relations with the Nation until very recently. With Desert Rock, the Navajo Nation is poised to set a precedent for other Native Nations in terms of their freedom to implement development projects. ${ }^{14}$ The zenith of this tension is the Indian Tribal Energy Development and SelfDetermination Act of 2005, which claims to put greater decision-making power in the hands of Native Nations in terms of land management and energy resources, but still remains fully entrenched within federal institutions and environmental requirements (Rosser 2010: 504).

On the Navajo Nation, activists and tribal leaders often agree on the value of advancing tribal sovereignty, viewing the federal government as an historical adversary and ally in this pursuit. Yet activists and tribal leaders often hold differing visions of the specific technologies that will ensure the politicalcultural self-determination inherent in their existence as indigenous nations. It is not inevitable that the two sides are often opposed: rather, oppositions have developed historically and are specific to Navajo environmental politics as it bears on debates over tribal sovereignty and landscape transformations. As discussed above, the groundswell of activism in the 1960s was in large part fueled by debates over energy projects, and that activism was manifest in grassroots and tribal leadership networks. The bind of the state being both adversary and ally faces indigenous environmental movements - at the same time it faces tribal leaders - who, because of colonial logics and legacies, must work both within and against the constraints of the state. Indeed, this is a "double bind," as Jessica Cattelino has argued, as Native Nations "require economic resources to exercise sovereignty, and their revenues often derive from their governmental rights; however, once they exercise economic power, the legitimacy of indigenous sovereignty and citizenship is challenged within settler society" (Cattelino 2010). However, with the economic development proposal that is Desert Rock, not only does settler society challenge the legitimacy of Navajo sovereignty, but Diné people themselves are raising poignant challenges. In various public forums, Diné tribal members are rethinking Navajo sovereignty through everyday engagements with the landscape as well as through the interpretive, intellectual work of translating Diné ethical and cosmological codes into contemporary energy and environmental policies.

\section{Political-ecological deployments of sovereignty}

While advocates of Desert Rock work to position the power plant as a sound technology of tribal sovereignty through its economic power to generate revenue and its political power to override the state of New Mexico's disapproval of the project, those critical of Desert Rock work to position Desert Rock as the

\footnotetext{
${ }^{12}$ Handout, Mary N. Etsitty, Executive Director, Navajo Nation Tax Commissioner, Panel at the 2007 Navajo Sustainability Conference, Diné College, Tsaile, Arizona, August 22, 2007.

${ }^{13}$ See Merrion v. Jicarilla Apache Tribe, 455 U.S. 130, 102 S.Ct. 894, 71 L.Ed.2d 21 (1982).

${ }^{14}$ There is a sense among many of the Navajo officials I interviewed that, because of the Navajo Nation's demographic and geographic size and political power in Washington, D.C., other Native Nations will "look to the Navajo Nation" for models on their own development projects and tribal-federal relations.
} 
antithesis of sovereignty - in fact, as the harbinger of a most certain dystopia. Through various modes of social and visual practice, activists position sovereignty as their value, too, complicating status quo characterizations (by Shirley, the media, and others) of two opposing 'sides' in the issue: pro-sovereignty tribal leaders facing off against sovereignty-eroding, non-Native activists. In fact, with the many instances and artifacts voicing the Desert Rock controversy (public hearings, tribal and regional newspapers, protest marches, online blogs, and meetings between tribal officials and environmental groups), the two 'sides' were all Navajo, and frequently one another's clan relatives. Thus, these were not polemical positions as much as they were networks of relations (understood through k'e in Diné philosophy), always bound by cultural practices of recognition and respect, as well as deep connections to Navajo landscapes inscribed in oral histories and in the Diné language. At the ten public hearings on the Draft Environmental Impact Statement for Desert Rock in the summer of 2007, one of the core themes to emerge in speakers' statements was the embattled nature of Navajo kinship or relationality $\left(k^{\prime} e\right)$. Whether $k^{\prime} e$ signified primarily clan relations or, more broadly, relations will all beings within and including the four sacred mountains was up for debate. That is, how to operationalize k'e in energy and environmental policy remained unclear. In the struggle surrounding Desert Rock, most Navajo environmental activists cultivated an ongoing dialogue with tribal leaders, making strong critiques of tribal policy proposals, but at the same time, they were also deeply invested in Navajo tribal sovereignty. In fact, in many instances, activists are also simultaneously located within the arenas of tribal governance. For instance, it is not uncommon for a leading activist or community organizer to become a Chapter President, or even to run for Vice-President of the Navajo Nation, as Earl Tulley of Diné CARE did in 2010.

Many critics of Desert Rock illustrated their visions of the collapse of sovereignty through images of a landscape ruined by more intensive energy development. Interestingly, these projections of a dystopic future also draw upon a repertoire of collective knowledge of the poisoned past (and in some cases, poisoned present), given the extent of radioactive contamination in certain areas of the Navajo landscape. In an exhibition entitled Connections: Earth + Artist $=$ A Tribute Art Show to Resistance to Desert Rock, first shown at the Center for Southwest Studies at Fort Lewis College in Durango, CO and later at the Navajo Studies Conference in Shiprock, NM, most of the participating artists projected the future of the Navajo landscape transformed by energy technologies. The following three paintings, all by Diné artists who reside on the Navajo reservation, express the profound despair that Desert Rock provoked among many Diné people (Figures 2, 3 and 4).

These three expressive works evoke infrastructural futures that also conjure memories of the past, recalling in varying degrees, the historical legacies of resource extraction that have transformed the political ecology of the Navajo Nation. Ed Singer's painting refers to the Nation's history of uranium extraction, addressing 'downwinders' (Southwesterners living downwind from the Nevada Test Site and other centers of nuclear weapons production and detonation). Singer, like other tribal members opposing Desert Rock, sees projects like Desert Rock as a continuation of this longer legacy of exploitation of Navajo natural resources for settler colonial gain (personal interview, 2008). Apart from his artistic work (shown in galleries in the U.S. and abroad), Singer addresses energy development, environmental, and tribal sovereignty concerns through his elected position as President of the Cameron Chapter of the Navajo Nation, where he has been helping construct a community-based, commercial scale wind power farm as a mode of local economic development. James Joe's haunting piece, Bleeding Sky, depicts his imaginary of the human and non-human impacts of future coal power production, with life replaced by vacant stares, barren landscapes, and medical prosthesis. A full-time rancher, Joe created this piece in response to the call for submissions sent out by the Connections curators, winning 'best in show' of the exhibition. Gloria Emerson's piece inverts the project's name from Desert Rock to 'Rock Desert', invoking a stark wasteland inhabited by disfigured bodies, void of other signs of life. For tribal members like Emerson, who reside very close to the proposed Desert Rock site, this kind of activist work is highly personal, yet it also openly challenges prevailing tribal energy policy in which coal power continues to reign supreme. 


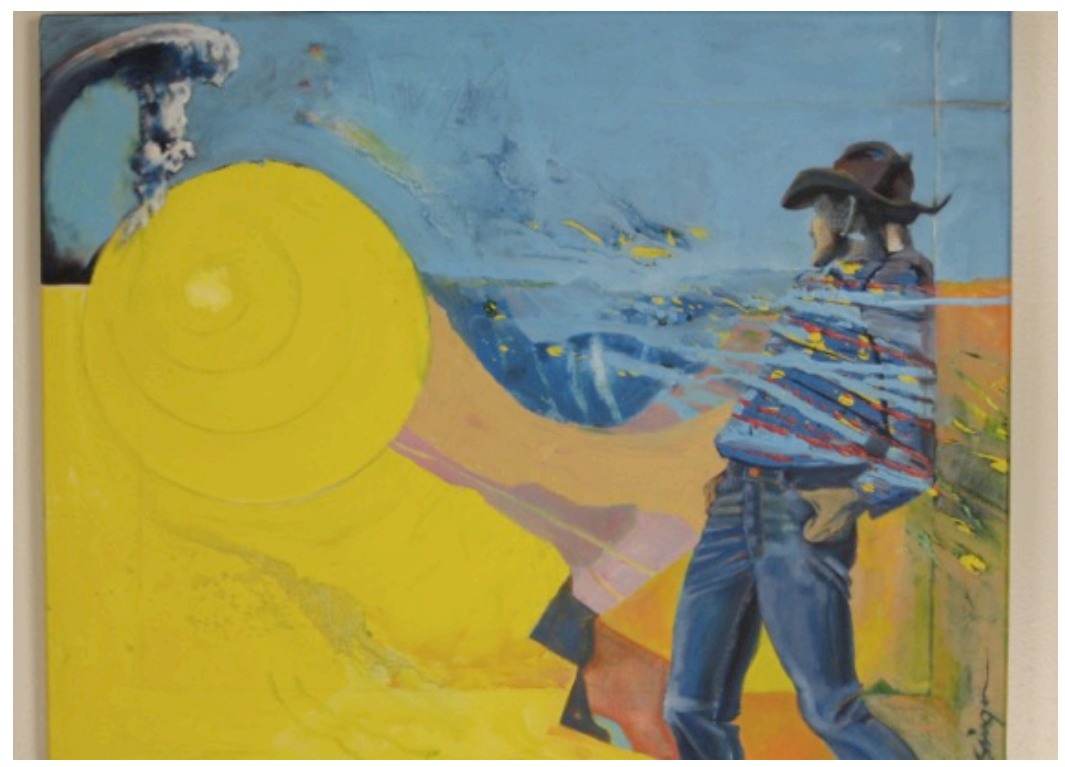

Figure 2: Dear Downwinders by Ed Singer (Diné). With permission.

Much like these artists who offer arresting, devastating images of future energy landscapes, other activists deploy a similar sense of suffering and powerful dystopia wrought by Desert Rock. They argue (on paper, in public speech, radio and television) that the proposed project is enmeshed in too many financial liabilities, legal compromises, regulatory uncertainties, environmental justice risks, and ethical transgressions. For example, many policy-oriented activists point to the near-certainty of costly carbon taxes that may be levied on polluters in the U.S. in the future, noting it remains unclear if the Navajo Nation or Sithe Global would be responsible for these extra taxes in the current joint venture arrangement. Other critics of Desert Rock point to the already diminishing livelihoods of rural ranchers, farmers, and sheepherders -particularly among elders who maintain these customary practices - whose lands and animals are already impacted by airborne and waterborne contamination flowing from the existing Navajo Coal Mine, Four Corners Power Plant, and San Juan Generating Station. Still others express concern about the lack of fundamental "balance" in an economic development agenda centered around coal extraction, noting broken promises and false hopes of the past, when uranium and oil development were touted as pathways to a prosperous future.

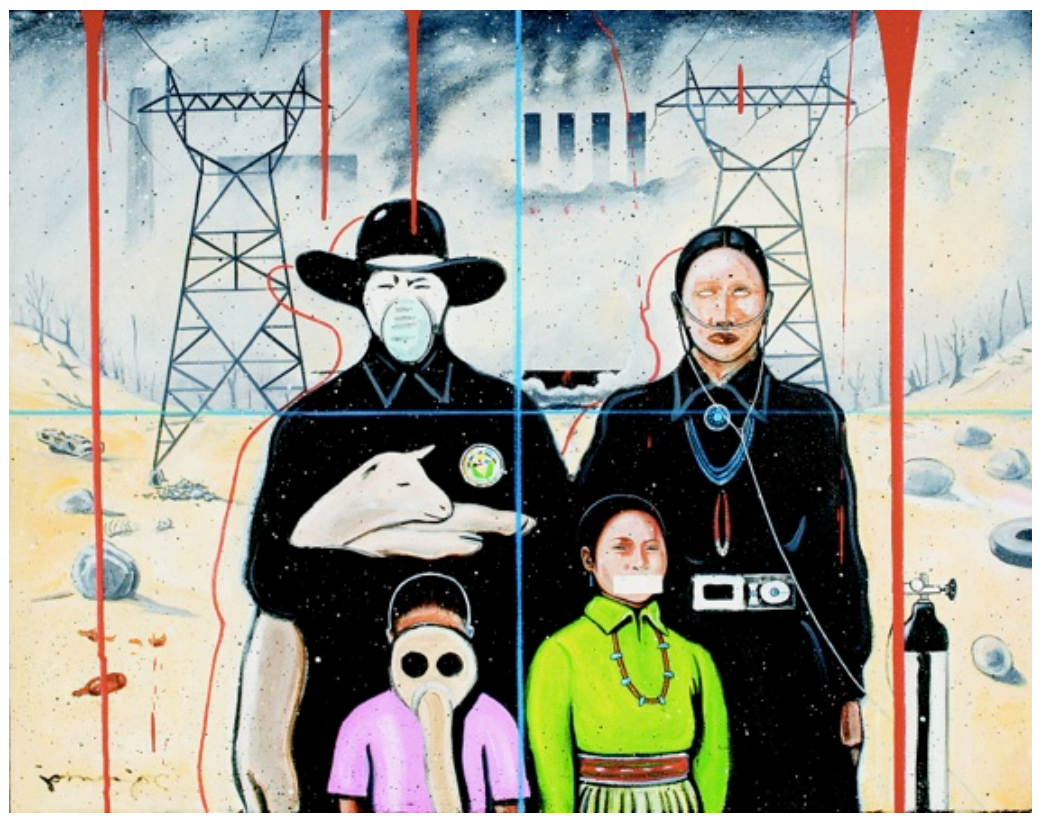

Figure 3: Bleeding Sky by James Joe (Diné). With permission. 
Central to activists' counter-imaginary of the Navajo energy landscape is the argument that tribal sovereignty would be best achieved through alternative power production technologies, especially commercial and community-scale wind and solar power. Navajo lands are optimally located for solar and wind development and, as early as the 1980s, some chapters of the Nation have collaborated with tribal- and non-tribal energy companies to install primarily residential scale solar photovoltaics and hybrid solar-wind systems on remote homesteads. This infrastructure has cut both ways: expanding communities' autonomy and capabilities in cases where extending existing electrical distribution lines is too costly or technically difficult, but on the other hand, frequently becoming a burden of technological expertise in areas where maintenance responsibilities become ambiguous (as occurred with the Klagetoh Chapter), resulting in castaway hardware and skepticism about alternative energy in general.

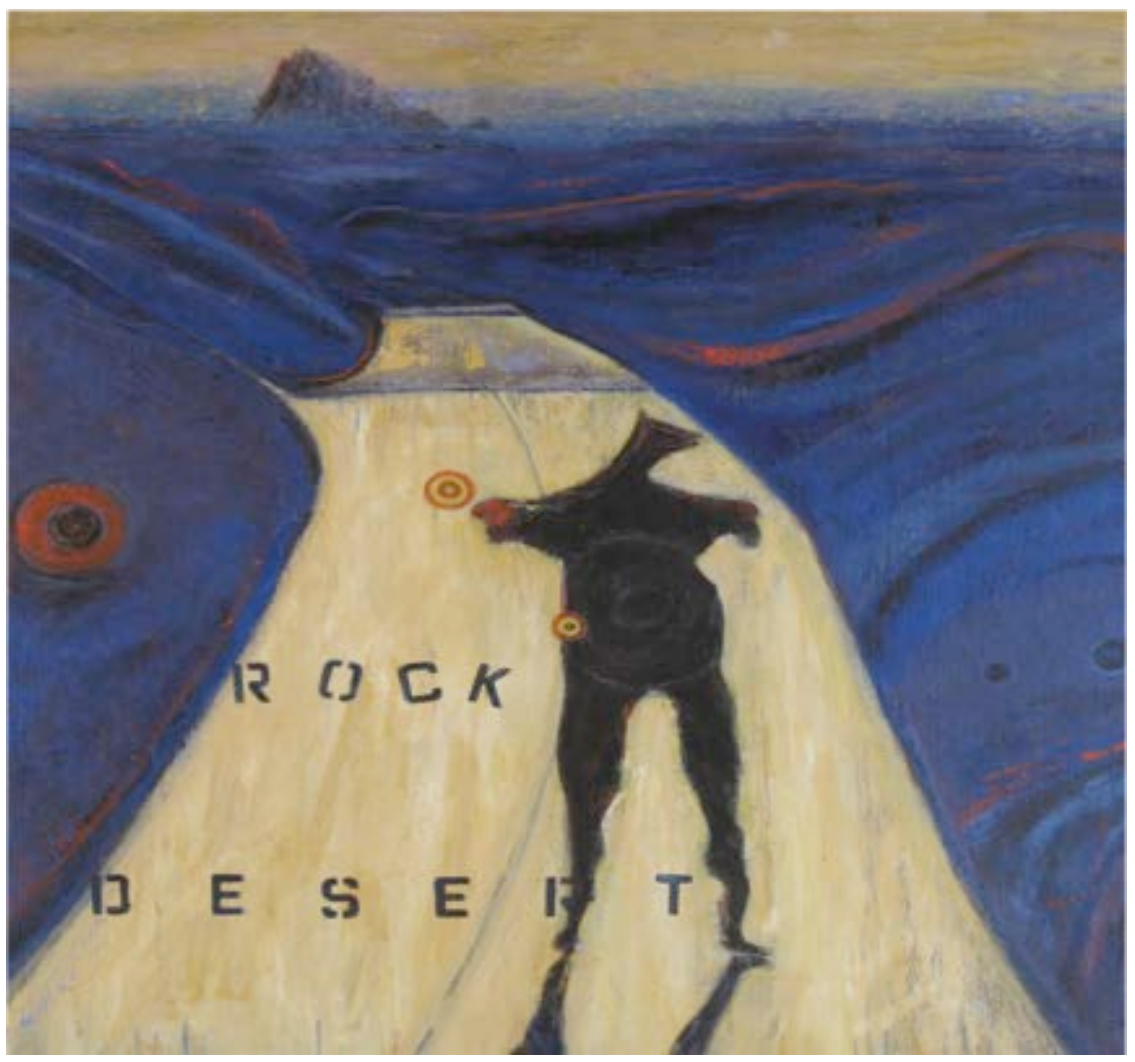

Figure 4: Rock Desert, by Gloria Emerson (Diné). With permission.

Renewable energy advocates working for the Nation (for instance, with the Navajo Tribal Utility Authority) and those working at the grassroots level through non-governmental organizations and as selffashioned energy entrepreneurs are well aware of this complicated technological history, and many are pursuing new solar and wind projects to increase community-based ownership over energy systems and tribal sovereignty, more broadly. For instance, in 2008, Diné CARE released a collaboratively researched report, titled Economic and energy alternatives to desert rock, detailing how a mix of solar and wind power technologies could replace the generating capacity of Desert Rock (Diné CARE 2008). Their report argued that this alternative mix of energy technologies would advance Navajo sovereignty in a safer, cleaner, and more secure manner while at the same time it would conform with Navajo Fundamental Law, a set of core ethical teachings founded in Diné cosmology. The Report integrated teachings from the creation stories in which the sun is the consort of the supreme Navajo deity, White Shell Woman, and the wind is the animus of life, its swirling path into our bodies made visible in the whorls on our fingertips. Much of the activists' organizing work, knowledge production, and political imaginary is built on the concept of a Navajo landscape powered by grid-tied wind farms and solar troughs, generating power for export as well as local 
consumption, surpassing New Mexico's own ambitious renewable energy standards. ${ }^{15}$ This is a vision of advancing Navajo sovereignty through the technological capability to generate tribal revenue through the Nation's vast renewable energy resources - and, at the same time, to provide locally harvested and distributed electrical power to nearby Diné families and communities living off the grid. This sense of sovereignty being bound up with environmental technologies and energy histories changes the way we consider the landscape. Landscapes are not a 'backdrop' or a canvas for human activity, but rather, are natural-cultural process of human and non-human interactions over time (Ingold 1993). Since the 1920s birth of the Navajo Nation as a political body (in the eyes of the settler state), Diné leaders have often worked to advance tribal sovereignty through particular landscape practices, namely: energy development projects. At the same time, activists and artists who imagine other possible terrains have challenged these official landscapes of power, advocating for landscapes of power defined by different kinds of environmental politics and ethics.

Diné peoples' reflections on the shifting meanings of Navajo sovereignty further reveal that strictly juridical interpretations of sovereignty fail to capture what is at stake for many tribal members engaged in energy debates. Instead, approaching this political ecology of coal - as Desert Rock makes visible - through a sense of territorial sovereignty as lived, embodied, and open-ended suggests that resistance to settler colonial logics operates in a political sphere beyond the courtroom: a sphere in which the salience of 'culture' and the 'sacred' are unsettled, contested terrains of struggle. For instance, during the Environmental Impact Statement public hearings on Desert Rock in June and July 2007, concurrent direct action events, Tribal Council Chambers proceedings, and in private interviews, tribal members' testimonials grounded sovereignty in a particular place and in specific practices, animated through a variety of infrastructural, land-based, ethical projects. Tribal members with varying positions on Desert Rock articulated tribal sovereignty with Navajo energy development, relating some of the complex analytics and emotions embedded in sovereignty. Harry Walters, anthropologist and former curator of the museum at Diné College in Tsaile, spoke of sovereignty in these terms:

Sovereignty means that you have a right to do whatever you want to without interference from outside. Desert Rock is a test of Indian culture. How, when [we] say, 'sacred things, sacred mountains, sacred earth, the air and so forth', like that, to see, what do they mean? Sacred only to them? If they desecrate it for themselves, it'll be alright, but if it's an outsider, then it's wrong? This is a test of that and then we do a thing like Desert Rock. What we complain about, we're doing it in the name of sovereignty. ${ }^{16}$

Walters' perspective on 'outsiders' and their role in energy development and desecration of the land is also shaped by his upbringing in the reservation community of Cove, Utah, where his father worked in the local uranium mine in the 1950s and where tailings piles (exposed remnants of the mines) continue to lay open in the hills above the Cove elementary school, their 'yellowcake' glittering in the sun. Before his academic career, Walters himself labored in a uranium and vanadium processing facility in Shiprock, and remains amazed that he hasn't developed cancer or other serious health problems like many of his former coworkers. His take on sovereignty is rooted in this personal and collective history of energy extraction, and he views Desert Rock through this experience. As a 'test of Indian culture', Walters sees Desert Rock as a fundamental challenge to Diné people to articulate what matters: in his formulation, sacred elements versus economic gain.

\footnotetext{
${ }^{15}$ New Mexico's Renewable Portfolio Standard (RPS) mandates 20\% of energy be generated from renewable sources by the year 2020. This compares with Arizona's more conservative projections of $15 \%$ by 2025 and Colorado's more ambitious projections of $30 \%$ by 2020 . The Navajo Nation, which cuts across these three states, has not set any such standards of its own. For the sake of national comparisons, the highest percentages have been set by the states of Hawaii, with $40 \%$ by 2030 and Maine, which has had an RPS of $30 \%$ since the year 2000 and projects $10 \%$ of additional renewable resources by 2017. These are followed by projections of 30\% (like Colorado) in New York by 2015 and by $25 \%$ in West Virginia by 2025. These are among the 24 states plus the District of Columbia with RPS policies in place, to date. Of course these energy potentials are utterly dependent on the states' average wind speed, number of consistent solar hours, and other geographically specific particulars. Source: U.S. Department of Energy. (http://apps1.eere.energy.gov/states/maps/renewable_portfolio_states.cfm)

${ }^{16}$ Walters, Harry. Personal interview, June 18, 2008.
} 
One of the more vocal opponents of Desert Rock, but also positioned inside tribal government as both a long-term employee of the Navajo Housing Authority and a recent candidate for the office of VicePresident of the Navajo Nation, Earl Tulley expresses sovereignty's fundamental tension as codified versus un-codified law:

There are two different notions here. The sovereignty of a government is what is written in the text of Title 2 [Tribal Code], of how the government was recognized. The sovereignty of the people is an unwritten text. It is the natural law. That is the conflict. ${ }^{17}$

This 'unwritten text' is precisely what Desert Rock brought into the public debate on Navajo energy futures. The question became how to build a landscape that reflects and perpetuates the values commonly agreed upon as meaningful, but contested as how to implement in practice. Tribal members on all sides of the debate over Desert Rock (and over energy issues, more broadly) upheld a collective commitment to Diné 'natural law' (also called Fundamental Law of the Diné) but there was vast internal differentiation as to how to translate this natural law into contemporary policy. Tulley sees a foundational dissonance: the 'sovereignty of a government' does not always map neatly onto the 'sovereignty of a people', and thus the conflict lies in what is written and codified versus that which ultimately cannot be written or regulated - despite it being a widely accepted and valued modality of 'law.' The dilemma appears unresolvable.

However, Diné CARE founder and elder Anna Frazier (of Dilkon, AZ) suggests a possible resolution to this dilemma that takes this abstract ambiguity of codified versus natural law and situates it in the land, reminding us of the stories and places constituting Diné ethics and landscapes. Her understanding of sovereignty is not bound by juridical or state relations, but rather, is a kind of relational sensibility that predates the state. As discussed earlier, the mountains to the north, south, east and west become the material definitions of sovereignty emplaced, situated, and historically particular to the experience of the Diné people before and long after their Long Walk home from Bosque Redondo in 1868:

So that's sovereignty to me, that's what it is: that bubble that we live in, the four sacred mountains. Within those sacred mountains is where the law is, the law that was given to us, the Fundamental Laws. So we live by that within these mountains. To me, that's sovereignty. ${ }^{18}$

This formulation of sovereignty is territorial, embodied, and emplaced. There is an acknowledgement (following Dennison's warning, addressed in the Introduction) that at stake are both territories and bodies. Sovereignty is, in this sense, a way of living and being in a very specific landscape. For Frazier (and many others that expressed a similar stance), sovereignty is not only worked out in tribal and federal courts of law, but is worked out in everyday life in Diné Bikeyah (Navajo homeland), always mindful of the complex, shifting and fervently debated 'natural laws' constituting ethical life. The sense of separation Frazier expresses as 'that bubble that we live in' further suggests a spatial, historical, and cultural-political difference that becomes visible when both written and unwritten Navajo sovereignty is challenged through contemporary environmental politics. Walters, Tulley and Frazier each articulate an alternative source of legitimacy within the concept of sovereignty: a source linked with a particular environmental cosmology and being put to test through the Desert Rock struggle. In other words, each person situated sovereignty as possessing a deep source of authority, exceeding status quo, juridical understandings of sovereignty most often under negotiation in court challenges to federal primacy.

As a final example: in April 2014, the Diné Food Sovereignty Initiative, a project of the Diné Policy Institute, released a report based on several years of research into Navajo food systems, finding that the current configuration of food access, land use, knowledge, distribution, and consumption is a major contributor to poor health among Diné people living on the reservation (Eldridge et al. 2014). The

\footnotetext{
${ }^{17}$ Tulley, Earl. Personal interview, February 26, 2008.

${ }^{18}$ Frazier, Anna. Personal interview, June 13, 2008.
} 
collaborative authors of this report understand sovereignty through epistemology and practice, much as Frazier, Tulley, Walters and others do. They argue:

...these recommendations assert Diné Sovereignty, of not only the Navajo Nation government but of the people, Diné lifeways, and knowledge so that the Navajo Nation can move to rebuild a self-sufficient food system where federal and state jurisdiction are detrimental to this process, and to reestablish a food system that meets the needs of the Diné people in ways appropriate to them (Eldridge et al. 2014: 62, emphasis mine).

The authors critique the current capitalist model, concentrating healthier food choices at markets in off-reservation border towns, causing a continual bleed of cash rather than local reinvestment ${ }^{19}$; stifling Diné growers who lack the capacity to produce and distribute greater quantities of food; and obscuring the vitality and possibility of the informal, microenterprise and home-based food economy found in mobile food vendors, a practice "already actively creating a Navajo Nation food economy outside limitations of a formal economy" (Eldridge et al. 2014: 60; see also Gibson-Graham 2006). This work to "restore the local food infrastructure" on the Navajo reservation through farmers markets, mobile grocery stores, community supported agriculture, and enhancing existing food access points is a mode of critical practice situated within a broader, global movement for food sovereignty in indigenous communities (Cadieux and Slocum 2015). What makes this most significant to the present discussion is the interpretation of sovereignty as a kind of lived, territorial sovereignty: distinctly practice-based, material, and embodied. Asserting sovereignty through food - as through energy development - emplaces debates about self-sufficiency and political independence quite literally in a particular environment; but in the context of settler colonialism in which this movement operates, this is not conventional, global environmental politics but rather, a politics of being that cannot be parsed from the land in which it is located.

\section{From identity to ontology: sovereignty is about who we are}

The interpretive turn in these diverse conceptions of sovereignty vis-à-vis energy and food development lies in these and other activists' refusals to solidly identify with environmentalism. ${ }^{20}$ Despite their work on solar energy development, food system restoration, climate change, or water rights, global environmentalism is not the primary position from which these activists critique unbridled coal development or settler colonialism more broadly. Their refusal of environmentalism suggests a different mode of politics and sensibility about sovereignty that is grounded in a specific territory and its complex history, but not in ways conventionally associated with the 'protection of nature' in dominant strains of environmentalism.

Speaking in the Manhattan boardroom of Sithe Global Power, the energy corporation behind Desert Rock, Anna Frazier insisted that Navajo Fundamental Law guided her opposition to the proposed power plant. During this unusual meeting between two of Sithe's top executives and several members of Diné CARE, Frazier and her colleagues from the Navajo Nation were continually met with the C.E.O.s proclamations of his own environmental commitments and his personal desire - as a self-proclaimed environmentalist - to build energy infrastructure in order to transform global poverty. He supported his personal testimony with claims about Sithe's global energy operations and the company's cutting edge corporate social responsibility portfolio. From coal-fired power plants in the U.S. and Canada to hydropower in the Phillipines and biofuels in Liberia, Sithe is setting new industry standards with its approach, the C.E.O. assured Frazier and the others. "I'm one of those environmentalists that still believes in hydroelectric", he said, describing the award Sithe received for its 'relocation strategy' of the 5,000 Filipino villagers removed from their homes to make way for the hydropower dam. For the Diné activists at the table, the Sithe executive embodied the precise politics of nature that more than two decades of environmental justice movements and theory have challenged. His performance of what he offered as a universal environmental

\footnotetext{
${ }^{19}$ The authors find that nearly 70\% of Navajo money is spent in off-reservation communities (Eldridge et al. 2014: 58).

${ }^{20}$ This rejection of mainstream environmentalism and the identities associated with it is consistent with broader networks of environmental justice and is discussed at length elsewhere. See Allen et al. 2007; Di Chiro 1996; Rocheleau et al. 1996; and Sherry 2002.
} 
identity worked, in effect, only to undermine the credibility he so ardently sought to establish with his visitors.

The encounter between members of Diné CARE and Sithe Global executives happened within days of vivid sidewalk protests outside the Sithe headquarters, organized by the Black Mesa Water Coalition and Doodá Desert Rock, two other Diné organizations opposing future coal development on the Navajo Nation. This was all part of a week of rearticulating indigenous politics, as the Seventh Permanent Forum on Indigenous Peoples was underway at the United Nations. This transnational gathering brought Diné groups into global networks of coal power critics and renewable energy advocates, creating opportunities for Diné activists to dialogue with Maasai wind farm advocates, Quechua anti-mining activists, and Mongol herders: the commonalities and differences in their struggles over energy development energized the Diné CARE delegation, bolstering their resolve when they met face to face with Sithe executives.

The boardroom meeting produced a number of unexpected, awkward, and revealing moments, confirming the deep-seated ways in which indigeneity remains associated with the environment in the popular imagination. The C.E.O.'s discursive risk was to attempt, through detailed eulogies of global renewable energy projects, to bridge the obvious cultural and historical difference between his position and the Diné activists' positions vis-à-vis what he presumed to be the secure pathway of shared politics: environmentalism. He did not realize, of course, that he embodied the "space of the imaginary environmentalist" (Holland 2003) that Diné CARE has worked to disrupt since their earliest efforts in Dilkon, Arizona in 1989. The C.E.O.'s self-positioning suggests that he banked on environmentalism (as a politics) and being an environmentalist (as an identity) as a means of reducing the presumed distance between the indigenous and the non-indigenous.

Two months later, Frazier reflected upon her experience in New York in a manner that deepened my understanding of the fundamental discord and analytic productivity of this tense encounter. Sitting in her living room, she said:

You know, when you're way over here on the reservation, you read about all these corporations, oil companies, big corporations sitting there like in an ivory tower or whatever ... they don't see what's happening down here to the people. These are people, human beings, their hearts are pumping, they live, they're alive, these people that are impacted by all this pollution ... I was there and all those things I was thinking about. And I was angry. I wanted them to know the difference between our culture and theirs ... They have more power, but they have the power because they have the money. And our people do not have the money. But we have that power, too, that we've always had ... And the guy kept saying he was an environmentalist! I was so upset about that. He was looking at us like we're a bunch of environmentalists, too, just like all of these NGOs, these big environmental corporations, organizations, whatever. But to me, we are fighting for who we are. That's the way I see us. Our fight is different, I think. Who we are, what we want our children to be, to live in this area where we live, on our land here, to continue to live here and not to be thought of as people that don't have anything, people that know nothing. ${ }^{21}$

As this recollection suggests, the boardroom encounter produced more than a debate over the technical, financial, scientific and policy pros and cons of building a new coal fired power plant on the Navajo Nation. Rather, it was a confrontation of difference, generating a refusal that contains within it the ember of an emergent, post-environmental politics. The encounter revealed that at stake - as throughout the wider energy debates surrounding Desert Rock - was the problem of, in Frazier's words, "who we are." Yet this is not a straightforward 'cultural' difference or even 'indigenous' difference in a categorical or essentialist sense. The problem, rather, is a difference between lived, ethical worlds, worlds that are populated by different experiences, concerns, beings, and legacies that render their encounter partially incommensurable. The incommensurability, and slippage, of environmentalism is a way of reading how these actors are working on very different political projects. As Escobar argues, political struggles are often an "articulation of difference" made within a wider "economy of power," irreducible, in this case, to the category of the

\footnotetext{
${ }^{21}$ Frazier, Anna. Personal interview, June 13, 2008.
} 
indigenous as commonly understood. In other words, the "who we are" at stake is not an "ethnic identity," but more of an "ethical commitment" (Escobar 2008: 203).

The encounter with Sithe executives and the urgent discussions surrounding sovereignty and the landscape suggests that the stakes of Desert Rock exceed environmental protection, as the struggle was widely cast by the media. There is a different ethical commitment at work, marked by a difference that is irreducible to simply 'being Navajo', although being Navajo has something to do with this distinction. In her analysis and dialogic self-positioning against environmentalism, the fundamental matter of concern for Frazier is not 'nature' or 'the environment' as a thing in itself to be protected - as enduring, essentialist tropes of North American indigeneity tend to assume. Instead, her refusal suggests an ethical commitment to guarding and generating something that escapes conventional, globalized notions of the environment or environmentalism. Frazier, and many others, are invested in protecting and producing a particular place and ethical world, in which 'our way of life' is sustained. This is evident in her characterization of the energy executives as people who, located in their 'ivory tower', were unable to 'see' the world of 'the people' on the Navajo Nation.

The real thrust of Frazier's anger concerned the epistemic and ethical disjuncture that the C.E.O.'s deployment of environmentalism suggested. Her sense that he was "looking at us like we're a bunch of environmentalists" attempted to eclipse the ethical commitments that she, and others, felt were really at stake in the matter. Rather than being an environmentalist, she argued, "we are fighting for who we are." This suggests a commitment that involves asserting the future through enabling the collective identity of future generations, ensuring a lived identification with a specific and historical landscape, and not being identified through notions of material and epistemic deficiencies. Thus, the other side of her refusal of environmentalism is the affirmation of a way of being in a particular place that is itself a practice of a collective, ethical commitment ("our way of life") and sense of difference ("who we are").

For Frazier and many others who share her political project, sovereignty is emplaced. It is territorialized, as she tells us, "in the bubble that we live in, where the Law was given." Yet, sovereignty is also territorialized, I would argue, for the Navajo Nation leaders and other tribal members supporting Desert Rock. They, too, openly recognize the spatial and temporal significance of the four sacred mountains, the supremely defining formations of Navajo landscapes of power, shaping Navajo internal relations. However, their dominant conceptions of sovereignty and environmentalism operate within the framework of federal primacy, regulatory processes, and policy negotiations. This is a colonial regime of power in which the Navajo landscape is located, but not accorded its full cosmological significance.

In conclusion, this shift toward an appreciation of lived, territorial sovereignty expands our notion of what politics is and might yet become, moving beyond strictly juridical formations and into a realm where environmentalism writ large is not the primary position of sociocultural critique on matters of "nature". It also opens an ethnographic space for political ecology to attend to specific territorial practices as articulations of self-determination and autonomy and possible sites of challenge to settler colonial logics. Ten years of tracing the cultural politics surrounding the project suggests to me that these are the emerging ethics being negotiated through Desert Rock, despite its immaterial status and consistently contested future. Even with its slow fall from grace, the proposed coal plant has advanced tribal sovereignty, by making more visible the strong role of Navajo elected and grassroots leaders as social actors in national and transnational energy and environmental debates. In our present moment, as the Navajo Nation "doubles down on coal" (Curley 2013), these questions and alternative perspectives on the collective energy future seem ever more acute and urgent. The Navajo Nation's 2013 controversial purchase of the Navajo Coal Mine (from Australian transnational BHP Billiton), the feeder mine for the existing Four Corners Power Plant and proposed mine for Desert Rock, immediately precipitated the formation of a Navajo Transitional Energy Corporation (NTEC), a tribal venture whose only infrastructural 'transition' appears to be more sophisticated coal processing technology, with minimal allowance for wind and solar power projects. Transition, in this instance, is a discursive move only: reliance on carbon resources remains business as usual. 
The empty sign of environmentalism - much like the "space of the imaginary environmentalist," as Holland (2003) argues - challenged in theory and practice by Diné tribal members and organizations intimately engaged in energy policy debates, demands more creative frameworks for apprehending nature, while still exploring the salience of peoples' lived experiences in specific landscapes. Such (neo)realism takes seriously the lived experience of a material world as well as the shifting constructions, performances, and discourses that produce the territories we (analysts) tend to present as 'nature' and the practices we tend to apprehend as 'culture.' As Isabelle Stengers' political ecology commands us to take "the river as a cause for thinking" (Stengers 2005), I suggest - with my Diné colleagues -- that we might consider taking the rainbow as a cause for thinking (differently) about Diné sovereignty. Such rethinking requires an expansive reconceptualization of the site(s) of sovereignty practice, beyond the courtroom, we might say. It requires further ethnographic engagement with diverse articulations of sovereignty with ongoing cultural-territorial practices of Diné people: from basketball games to business site leases, from hauling potable water to harvesting piñons, from tour-guiding in Canyon de Chelly to reviving dry land farming techniques, and as the trajectory of this particular research suggests, from off-grid, domestic solar photovoltaic installations to increased energy mineral extraction in one of the most productive coal mines in Indian Country.

Energy politics and practices at all scales - tribally-owned operations and backyard boutique mines, tribal utility authority solar systems, and social entrepreneurial renewable projects - constitute energy's sociotechnical conduits (Wilhite 2005), necessary for approaching the lived, territorial sovereignty, which is assemblage of environmental concerns, livelihood, economies, and cultural politics. One of environmental anthropology's greatest contributions to the fields of political ecology and critical Native American/Indigenous Studies is the culturally particular, careful ethnographic attention to these complex articulations of sovereignty vis-à-vis energy politics, cultivating an awareness for the cosmologies of place and landscape that perhaps do not wear the banner of "environmentalism." Finally, given the urgent political project of tribal sovereignty within the settler colonial logics facing Native Nations, political ecologists might be of (better) service to these struggles, by reading for new practices, divergent meanings, absences, and contradictions within the standard repertoires of political action, thus underscoring alternative and emerging conceptions that might enable us to remain "engaged in the experimentation of the difference that what [we] know can make in the formulation of the issue and its envisaged solutions" (Stengers 2005: 998). As the planet increasingly - and unevenly - feels effects of climate change, and as the Navajo Nation approaches its centennial as a recognized political body constructed by empire's desire for oil, the possibility of designing infrastructural futures that do not perpetuate settler colonial logics of power is perhaps one of the most promising ways forward.

\section{References}

Allen, K., V. Daro, and D. Holland. 2007. Becoming an environmental justice activist. In Sandler R. and P. Pezzullo (eds.) Environmental justice and environmentalism: the social justice challenge to the environmental movement. Cambridge, MA: MIT Press. Pp 105-134.

Aronilth, W. 1992. Foundation of Navajo culture. Tsaile, AZ: Diné College.

Auyero, J. and D. Swistun. 2009. Flammable: environmental suffering in an Argentine shantytown. New York: Oxford University Press.

Basso, K. 1996. Wisdom sits in places: landscape and language among the Western Apache. Albuquerque: University of New Mexico Press.

Begaye, E. 2006. The Black Mesa controversy. Cultural Survival Quarterly 29(4): 29-31.

Biersack, A. 2006. Introduction. In Biersack A. and J.B. Greenberg (eds.) Reimagining political ecology. Durham: Duke University Press. Pp. 3-40.

Biolsi, T. 2005. Imagined geographies: Sovereignty, indigenous space, and American Indian struggle. American Ethnologist 32(2): 239-59.

Blakie, P.M. and H.C. Brookfield. 1987. Defining and debating the problem. In Blakie, P.M. and H.C. Brookfield (eds.) Land degradation and society. London: Methuen. Pp. 3-26.

Blueeyes, G. 1982. Sacred mountains. In Between sacred mountains. Rock Point, AZ: Rock Point Community School Pp. 2. 
Brugge, D., T. Benally and E. Yazzie-Lewis 2006. The Navajo people and uranium mining. Albuquerque: University of New Mexico Press.

Bruyneel, K. 2007. The third space of sovereignty: the postcolonial politics of U.S. Indigenous relations. Minneapolis: University of Minnesota Press.

Burke B.J. and B.W. Shear. 2014. Introduction: engaged scholarship for non-capitalist political ecologies. Journal of Political Ecology 21: 127-144.

Byrd, J.A. 2011. The transit of empire: Indigenous critiques of colonialism. Minneapolis: University of Minnesota Press.

Cadieux, K.V. and R. Slocum 2015. What does it mean to do food justice? Journal of Political Ecology 22: $1-26$.

Carroll, C. Forthcoming. Roots of our renewal: ethnobotany and Cherokee environmental governance. Minneapolis: University of Minnesota Press.

Carse, A. 2013. Nature as infrastructure: making and managing the Panama Canal watershed. Social Studies of Science 42 (4) 539-563.

Casas-Cortés, M., M. Osterweil, and D.E. Powell. 2008. Blurring boundaries: knowledge-practices in contemporary social movements. Anthropological Quarterly 81(1):17-58.

Casas-Cortés, M., M. Osterweil, and D.E. Powell. 2013. Transformations in engaged ethnography: knowledge, networks, and social movements. In Juris J.S. and A. Khasnabish (eds.) Insurgent encounters: ethnography, activism, and the transnational. Durham: Duke University Press. Pp.199228.

Cattelino, J. 2010. The double bind of American Indian need-based sovereignty. Cultural Anthropology 25(2): 235-263.

Chamberlain, K.P. 2000. Under sacred ground: a history of Navajo oil: 1922-1982. Albuquerque: University of New Mexico Press.

Cole, L.W. and S.R. Foster. 2001. From the ground up: environmental racism and the rise of the environmental justice movement. New York: New York University Press.

Curley, A. 2013. Navajo Nation doubles down on coal. Navajo Times. January 16, 2014, Pp.A-7. Window Rock, AZ.

Dennison, J. 2012. Colonial entanglement: constituting a twenty-first-century Osage Nation. Chapel Hill: University of North Carolina Press.

Dennison, J. 2014. The logic of recognition: debating Osage Nation citizenship in the twenty-first century. American Indian Quarterly 38(1):1-35.

Desmarais, A.A. 2007. La Vía Campesina: globalization and the power of peasants. London/Ann Arbor: Pluto Press.

Deloria, V. and C.M. Lytle. 1983. American Indians, American justice. Austin: University of Texas Press.

De la Cadena, M. 2010. Indigenous cosmopolitics in the Andes: conceptual reflections beyond "politics". Cultural Anthropology 25(2):334-370.

Di Chiro, G. 1996. Nature as community: the convergence of environment and social justice. In Cronon W. (ed.) Uncommon ground: rethinking the human place in nature. New York: WW Norton and Co. Pp.298-320.

Diné Citizens Against Ruining our Environment (CARE), prepared by Ecos Consulting. 2008. Energy and economic alternatives to the Desert Rock Energy Project. Durango, Colorado, January 12.

Eldridge, D. et al. 2014. Diné food sovereignty: a report on the Navajo Nation Food System and the case to rebuild a self-sufficient food system for the Diné people. Tsaile, AZ: Diné Policy Institute.

Escobar, A. 2008. Territories of difference: place, movements, life, redes. Durham: Duke University Press.

Escobar, A. 2010. Postconstructivist political ecologies. In Redclift M. and G. Woodgate (eds.) International handbook of environmental sociology. 2nd. edition. Cheltenham, UK: Elgar. Pp.91-105.

Gibson-Graham, J.K. 2006. A postcapitalist politics. Minneapolis: University of Minnesota Press.

Grossman, Z. 1995. Linking the Native movement for sovereignty and the environmental movement. Z Magazine 8(11): 42-50. 
Holland, D. 2003. Multiple identities in practice: on the dilemmas of being a hunter and an environmentalist in the USA. Focaal:European Journal of Anthropology 42: 23-41.

Ingold, T. 1993. The temporality of the landscape. World Archaeology 25(2): 152-174.

Ingold, T. 2011. The perception of the environment: essays on livelihood, dwelling and skill. New York: Routledge.

Ishiyama, N. 2003. Environmental justice and American Indian tribal sovereignty: case study of a land-use conflict in Skull Valley, Utah. Antipode 119-139.

Iverson, P. 2002. Diné: a history of the Navajos. Albuquerque: University of New Mexico Press.

Johnston, B.R., S. Dawson, and G. Madsen. 2010. Uranium mining and milling: Navajo experiences in the American Southwest. In Smith S. and B. Frehner (eds.) Indians and energy in the Southwest: exploitation or opportunity? Santa Fe: School of Advanced Research Press.

Kelley, K.B. and H. Francis. 1994. Navajo sacred places. Bloomington: Indiana University Press.

Lambert, V. 2007. Choctaw Nation: a story of American Indian resurgence. Lincoln: University of Nebraska Press.

Martínez-Alier, J. 2005. The environmentalism of the poor: a study of ecological conflicts and valuation. New York: Oxford University Press.

Martinez-Alier J., Anguelovski I., Bond P., Del Bene D., Demaria F., Gerber J.-F., Greyl L., Haas W., Healy H., Marín-Burgos V., Ojo G., Porto M., Rijnhout L., Rodríguez-Labajos B., Spangenberg J., Temper L., Warlenius R. and I. Yánez. 2014. Between activism and science: grassroots concepts for sustainability coined by Environmental Justice Organizations. Journal of Political Ecology 21: 19-60.

Masco, J. 2006. The nuclear borderlands: the Manhattan Project in post-Cold War New Mexico. Princeton and Oxford: Princeton University Press.

McCreary, T. and V. Lamb. 2014. A political ecology of sovereignty in practice and on the map: the technicalities of law, participatory mapping, and environmental governance. Leiden Journal of International Law 27: 595-619.

Middleton, E. 2010. A political ecology of healing. Journal of Political Ecology 17: 1-28.

Moore, D. 2005. Suffering for territory: race, place and power in Zimbabwe. Durham: Duke University Press.

Naor. 2014. Discussion at Infrastructural worlds conference, Duke University, Durham, NC.

Needham, A.T. 2014. Power lines: phoenix and the making of the modern Southwest. Princeton: Princeton University Press.

Ong, A. 2006. Neoliberalism as exception: mutations in citizenship and sovereignty. Durham: Duke University Press.

Osterweil, M. 2013. Rethinking public anthropology? Social movements, epistemic shifts and politics. Cultural Anthropology 28(4): 598-620.

Parker, A. 2014. Sovereignty by the barrel: Indigenous oil politics in the Bakken. Paper delivered at Native American Indigenous Studies Association Annual Meeting, Austin, Texas, May 28.

Pasternak, J. 2010. Yellow dirt: an American story of a poisoned land and a people betrayed. New York: Free Press.

Powell, D.E. and A. Curley. 2009. K'e, Hozhó, and non-governmental politics on the Navajo Nation: ontologies of difference manifest in environmental activism. World Anthropologies Network EJournal 4: 109-137.

Powell, D.E. and D.J. Long. 2010. Landscapes of power: renewable energy activism in Diné Bikeyah. In Smith S. and B. Frehner (eds.) Indians and energy: exploitation and opportunity in the American Southwest. Santa Fe: School of Advanced Research Press.

Redhouse, J. Forthcoming. The continuing long walk: removing the overburden.

Rifkin, M. 2009. Indigenizing Agamben: rethinking sovereignty in light of the 'peculiar' status of Native peoples. Cultural Critique 73:88-124.

Robbins, P. 2004. Political ecology: a critical introduction. Malden, MA: Blackwell Publishing. 
Rocheleau, D., B. Thomas-Slayter, and E. Wangari. 1996. Feminist political ecology: global issues and local experiences. New York: Routledge.

Rosser, E. 2010. Ahistorical Indians and reservation resources. Environmental Law 40:437-545.

Scott, R. 2010. Removing mountains: extracting nature and identity in the Appalachian coalfields. Minneapolis: University of Minnesota Press.

Sherry, J.W. 2002. Land, wind, and hard words: a story of Navajo activism. Albuquerque: University of New Mexico Press.

Shirley, Jr., J. 2009. Navajo Nation Press Release, Window Rock, AZ.

Stengers, I. 2005. The cosmopolitical proposal. In Latour B. and P. Weibel (eds.) Making things public. Cambridge: MIT Press. Pp. 994-1003.

TallBear, K. 2000. Comment of Kimberly TallBear regarding private fuel storage project on the Skull Valley Band of Goshute Reservation. Nuclear Regulatory Commission Atomic Safety and Licensing Board public hearing. June 24. Salt Lake City, Utah.

U.S. EPA Press Release, October 6, 2010. United States Environmental Protection Agency.

Voggesser, G. 2010. The evolution of Federal energy policy for tribal lands and the renewable energy future. In Smith S. and B. Frehner (eds.) Indians and energy in the Southwest: exploitation or opportunity? Santa Fe: School of Advanced Research Press.

Wilhite, H. 2005. Why energy needs anthropology. Anthropology Today (21) 3: 1-2.

Wilkins, D.E. 2003. The Navajo political experience. Lanham, MD: Rowman and Littlefield.

Wilkins, D.E. and K. Tsianina Lomawaima. 2001. Uneven ground: American Indian sovereignty and federal law. Norman, OK: University of Oklahoma Press. 